ACTA UNIVERSITATIS WRATISLAVIENSIS

No 3994

PRZEGLĄD PRAWA I ADMINISTRACJI CXXII

WROCEAW 2020

https://doi.org/10.19195/0137-1134.122.8

\author{
MARCIN ROMANOWICZ \\ ORCID: 0000-0003-3097-1310 \\ Uniwersytet Warszawski
}

\title{
HOMO IURIDICUS VERSUS ZOON POLITIKON - DOGMATYKA PRAWNICZA A WYTWARZANIE PODMIOTU (POLITYCZNEGO)
}

\begin{abstract}
Abstrakt: W refleksji nad politycznością prawa i prawoznawstwa wydaje się dominować pogląd, że polityczność poprzedza (chronologicznie lub strukturalnie) prawo. W konsekwencji to antagonizmy sfery polityki współkształtują prawo i jego zjawiska (praktykę prawniczą i prawoznawstwo). Teza o prymarności polityczności może być jednak poddana weryfikacji w drodze analizy zainicjowanej przez przewrotne pytanie o jurydyczne warunki, bez których nie jest możliwa polityczność par excellence. Refleksja nad ikoną Zoon Politikon odsłania warunek polityczności w postaci podmiotowości uczestników sfery politycznej, z kolei sięgnięcie po psychoanalityczną teorię J. Lacana pozwala uchwycić psychodynamikę upodmiotowienia „zwierzęcia mówiącego" (Zoon Logon Echon). Wprowadzenie zakazu (Symbolicznego zakodowanego w prawie) okazuje się warunkiem sine qua non ludzkiej podmiotowości. Wedle Pierre'a Legendre'a we współczesnym społeczeństwie to dogmatyka prawnicza reprodukuje podmiototwórczy Zakaz, a zatem „montuje” człowieka: Homo Iuridius, i „ustanawia jego życie”. Tym sposobem prawo i dogmatyka prawnicza ukazują się jako warunki powstania podmiotu (politycznego), a tym samym samej polityczności.
\end{abstract}

Słowa kluczowe: polityczność, polityka, Zoon Politikon (zwierzę polityczne), Zoon Logon Echon (zwierzę mówiące), Homo Iuridicus (człowiek prawny), podmiotowość, jurydyczność, zakaz, antropologia, psychoanaliza, prawoznawstwo, dogmatyka prawnicza, Jacques Lacan, Pierre Legendre

Czasem zjawiają się na świecie ludzie, którzy nie mogą już dłużej patrzeć na skandaliczny chaos życia i jego tajemnicze plenienie się.

Václav Havel ${ }^{1}$

1 V. Havel, Anatomia powściagliwości jednej ze stron, [w:] idem, Zmieniać świat. Eseje polityczne, Warszawa 2012, s. 21; wyróżnienia w tekście - M.R. 


\section{WPROWADZENIE (KLASYCZNE)}

Krytyczna filozofia prawa od dłuższego już czasu zestawia z sobą polityczność i prawo, prowadząc pogłębioną refleksję nad relacją zachodzącą pomiędzy tymi dwoma fenomenami społecznego życia osobników gatunku Homo sapiens sapiens. Z tych dociekań wyłania się teza o prymarności polityczności, wedle której polityczność — rozumiana jako sfera antagonizmu — poprzedza prawo i jego praktykę, a tym samym wywiera wpływ na kształt i funkcjonowanie domeny jurydycznej. Innymi słowy pozytywistyczny „szlachetny sen” o idealnie funkcjonującej maszynie prawa jest nieustannie nawiedzany przez potężną i nieustępliwą „nocną marę" politycznych ideologii².

W inicjowanych rozważaniach proponuję pochylić się nad przewrotnym pytaniem, które testuje odwrotnie zwrócony wektor relacji „,polityczność-jurydyczność". Pytanie brzmi: czy możliwe jest zidentyfikowanie takich warunków, bez których nie jest możliwa polityczność, a które to warunki mogą być spełnione jedynie przez prawo (pozytywne)? W poszukiwaniu odpowiedzi w pierwszej kolejności podejmuję się analizy arystotelesowskiej ikony człowieka jako „zwierzęcia politycznego" (Zoon Politikon), albowiem to właśnie ją ewokuje śmiała teza o polityczności jako fundamentalnej cesze ludzkiego bycia-w-świecie. Studium tej ikony (refleksja 1) prowadzi do wydobycia bardziej pierwotnej warstwy antropologicznej, to jest koncepcji człowieka jako zwierzęcia mówiącego (Zoon Logon Echon), która ukierunkowuje dalsze rozważania w stronę pytania o podmiotogenezę biologicznych jednostek ludzkich (refleksja 2). Ustalenie, jak przebiega upodmiotowienie „Zwierzęcia mówiącego”, wymaga sięgnięcia po koncepcję psychoanalityczną J. Lacana, gdyż właśnie ten autor i klinicysta przedstawił mechanizm wyłaniania się podmiotu ludzkiego z praktykowania mówienia. Psychoanaliza jako lingwistyka mówienia daje szczegółowy wgląd w proces podmiotogenezy, który przedstawiono w centralnej części rozważań. Prześledzenie topologii tego procesu prowadzi do figury Homo Iuridicus - człowieka tworzonego przez prawo, jako że to prawo zostaje wykryte w teorii J. Lacana jako czynnik konstytuujący człowieka w podmiotowości. Podmiot ludzki okazuje się „montowany” przez prawo (konstatacja 1), przez „monterów” w postaci urzędu sędziowskiego i dogmatyki prawniczej (konstatacja 2). W ocenie Pierre'a Legendre'a jest to we współczesnej ultranowoczesnej kulturze jedyna droga stabilnego upodmiotowienia ludzkich jednostek. W konsekwencji — to, co składa się na jurydyczność, czyli $\mathrm{P}(\mathrm{p}) \mathrm{rawo}^{3}$ i jego praktyka (aplikacyjna oraz naukowa), okazuje się warunkiem sine qua non polityczności. Relacje w diadzie „polityczność-jurydyczność” są zatem bardziej skomplikowane, niż przedstawia to teza o prymarności polityczności.

2 Nawiązanie do metaforycznych wyrażeń zastosowanych przez Herberta L.A. Harta, Eseje z filozofii prawa, Warszawa 2001, s. 121-142.

3 Wyrażenie „prawo" pisane od wielkiej litery oznacza w niniejszej refleksji każdą formę transcendentnej (to jest zewnętrznej wobec jednostki) normatywności, podczas gdy pisane z małej litery oznacza prawo pozytywne. 


\section{PYTANIE OTWIERAJĄCE O WARUNEK POLITYCZNOŚCI PRAWA I PRAWOZNAWSTWA}

Z etologicznego punktu widzenia osobniki gatunku Homo sapiens sapiens są zwierzętami stadnymi. Tworzą wspólnoty, które strukturyzują się i obrastają transmitowanymi synchronicznie i diachroniczne wzorcami zachowania, konstytuującymi oryginalne tożsamości kulturowe. W warunkach ograniczonych zasobów środowiskowych kryteria identyfikacji wpisane w tożsamość kulturową, pozwalające z jednej strony na odróżnienie „swojej” wspólnoty od „obcej”, a z drugiej — na bycie rozpoznawanym jako „swój”, a nie „obcy”, determinują biologiczne przetrwanie. Z tego powodu możność różnicowania „swoich” od „obcych” wydaje się wrastać w fundamentalne warstwy egzystencji człowieka i sferę spraw wspól-

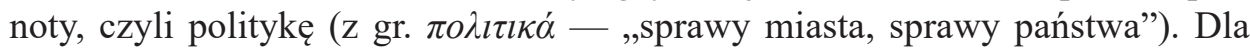
Carla Schmitta polityczność (das Politische) to właśnie sfera rozpoznawania „wroga” (Feind) i „przyjaciela” (Freund), a zatem obszar, dla którego konstytucji kluczowe jest ukształtowanie się kryterium identyfikacji, jednocześnie będące kryterium różnicowania ludzi poprzez przypisanie ich do odmiennych grup. To właśnie możność różnicowania stanowi nieredukowalne do żadnych zjawisk z innych dziedzin ludzkiej egzystencji differentia specifica pojęcia polityczności ${ }^{4}$. Polityczność jest prymarną sferą ludzkiej egzystencji, albowiem bezpośrednio wpływa na trwałość biologicznego życia poprzez sytuację walki, w której wróg może pozbawić mnie życia. Wróg (hostis) to nie osobisty nieprzyjaciel (inimicus), ale kategoria publiczna — wróg to grupa ludzi, która jest przeciwko „naszej” grupie, godząc w „nasze” zasoby lub sposób życia, czyli utrwalone synchronicznie i diachronicznie wzorce zachowania 5 .

Agonistyczna koncepcja polityczności C. Schmitta znajduje współcześnie swoich sukcesorów, pojmujących sferę politycznego Dasein człowieka jako przestrzeń niemożliwych do wyeliminowania z życia społecznego sporów, w których wokół spraw ekonomicznych, kulturowych i ideologicznych konstytuują się grupy „sojuszników” i „,oponentów”. Takie pojęcie nie jest też obce krytycznej filozofii

${ }^{4}$ Zob. M. Prószyńska, Schmittiańskie pojęcie polityczności. Neutralizacja w ogniu krytyki, https:/teologiapolityczna.pl/magdalena-proszynska-schmittianskie-pojecie-politycznosci-neutralizacja-w-ogniu-krytyki (dostęp: 15.03.2020).

5 Zob. C. Schmitt, Pojęcie polityczności, [w:] idem, Teologia polityczna i inne pisma, Warszawa 2012, s. 254-256.

${ }^{6}$ Zob. np. Ch. Mouffe, Polityczność. Przewodnik Krytyki Politycznej, Warszawa 2008, s. 24-26. Przekonanie, że myślenie w kategoriach „wrogów” i ,przyjaciół” jest podstawową cechą człowieka, przeniknęło też do innych obszarów nauk humanistycznych i związanych z nimi działań popularyzatorskich i publicystycznych, między innymi z zakresu historii XX wieku, o czym świadczy następujące stwierdzenie, tworzące puentę ponadsześćsetstronicowej narracji o sowieckim systemie obozów pracy przymusowej: „Każda z wielkich tragedii XX wieku była zjawiskiem niepowtarzalnym, jedynym w swoim rodzaju — Gułag, holocaust, masakry Ormian, masakra w Nankinie, Rewolucja Kulturalna, rządy Czerwonych Khmerów, wojny bośniackie — by wymienić tylko kilka. Każda z nich zdarzyła się w odmiennym kontekście historycznym, wynikała z odmiennych uwarunkowań 
prawa, która celem uporządkowania własnych analiz i dyskusji wokół polityczności prawa i prawoznawstwa wyróżnia trzy możliwe obszary znaczeniowe tego pojęcia:

1. polityczność jako wymiar antagonizmu, który leży u podstaw każdego społeczeństwa (the political);

2. polityczność jako zestaw praktyk i instytucji, które w obliczu antagonizmów mają tworzyć porządek umożliwiający ludzkie wspólistnienie (politics);

3. polityczność jako zbiór dyrektyw, których realizacja ma zapewnić realizację wcześniej wybranego celu (policy) ${ }^{7}$.

Relacja zachodząca pomiędzy pierwszym a drugim znaczeniem jest jasna: polityczność jako antagonizm (the political) rozsadza każdą zbiorowość ludzką, zagraża koegzystencji osobników Homo sapiens sapiens, a zatem potrzebna jest odpowiedź w postaci instytucji społecznych i ich utrwalonych praktyk, które mają na celu tworzyć przestrzeń nieprzemocowego rozwiązywania sporów (politics). Trzecie znaczenie pojęcia polityczność wydaje się wolne od rysu antagonistycznego, lecz także ono wpisuje się w pewien logiczny ciąg, którego zasadą jest konflikt: instrumentalnie ujęta polityczność — jako zbiór dyrektyw służących osiągnięciu wybranych uprzednio celów (na przykład „,polityka zagraniczna”, ,polityka rolna”, „polityka społeczna”) — lokuje się na poziomie operatywnym, na którym możność działania otwiera się dopiero po rozwiązaniu sporów o cele, które mają być urzeczywistnione. Polityki (policies) okazują się zatem operatywną funkcją zdarzeń dziejących się na poziomie polityczności w pierwszym znaczeniu (the political).

W konsekwencji polityczność jako antagonizm okazuje się znaczeniem podstawowym, cechującym się ,intelektualnym magnetyzmem”, skupiającym uwagę badaczy zadających sobie pytanie o prawdziwość tezy o apolityczności prawa i nauk prawnych $^{8}$. Poszukiwania i analizy w tym nurcie metarefleksji prawoznawczej wy-

kulturowych i ideologicznych. Wspólna im była tylko nasza — ludzka — zdolność do degradacji, niszczenia i odczłowieczania innych istot ludzkich, do przekształcania sąsiada we »wroga«, do sprowadzania wroga do poziomu robactwa, które należy wytępić, lub chwastu, który należy wyplenić. Powtarzam raz jeszcze - to nasza, ludzka zdolność do traktowania ofiary jako bytu niższej kategorii, uosobienie cech zła, które należy izolować, eksterminować lub wygnać" - A. Applebaum, Gutag, Warszawa 2018, s. 619-620.

7 Zob. R. Mańko, W stronę krytycznej filozofii orzekania. Polityczność, etyka, legitymizacja, Łódź 2018, s. 147-151; idem, Nauki prawne wobec problemu polityczności: zagadnienia wybrane z perspektywy jurysprudencji krytycznej, „Archiwum Filozofii Prawa i Filozofii Społecznej” 2018, nr 3, s. 39-41 (autor ten wskazuje, że przywołany trójpodział zaproponował na podstawie ustaleń Ch. Mouffe i M. Zamboniego); A. Sulikowski, R. Mańko, J. Łakomy, Polityczność prawa i ogólnej refleksji nad prawem: wprowadzenie, „Archiwum Filozofii Prawa i Filozofii Społecznej” 2018, nr 3, s. 5.

8 Pytanie to zostało już wielokrotnie zadane; zob. np. M. Paździora, M. Stambulski, Co może dać nauce prawa polityczność? Przyczynek do dalszych badań, „Archiwum Filozofii Prawa i Filozofii Społecznej” 2014, nr 1, s. 55-66; A. Bator, P. Kaczmarek, Polityczność nauki prawa i praktyki prawniczej - wprowadzenie, „Przegląd Prawa i Administracji” 110, 2017, s. 9-11; T. Gizbert-Studnicki, Filozofia polityczna a pozytywistyczna teoria prawa, „Przegląd Prawa i Administracji” 110, 2017, s. 15-39; J. Zajadło, Prawoznawstwo — polityczność nauki czy nauka polityczności?, 
dają się oparte na założeniu, które można określić mianem tezy o prymarności polityczności. Rekonstruując jej treść, można podać jej dwa warianty:

1. polityczność poprzedza prawo, jego praktykę i nauki temporalnie, to znaczy (pre)historycznie pierwsze konflikty pomiędzy grupami osobników Homo sapiens sapiens, skazanymi na kooperację przez presję środowiskową (ewolucyjną), były racją do „wynalezienia” podstawowych systemów normatywnych: moralności i prawa, które służą budowaniu ładu społecznego i supresji antagonizmów wariant chronologiczny;

2. polityczność poprzedza prawo, jego praktykę i nauki w porządku intelektualnym, to znaczy polityczność jest podstawową cechą człowieka, której uprzednie przyjęcie pozwala budować wyjaśnienia, a nawet teorie, funkcji prawa w życiu społecznym - wariant strukturalny.

Tezę o prymarności polityczności można rozpoznać jako intelektualne następstwo przeświadczeń, że polityczność jest cechą immanentną samego społeczeństwa ${ }^{9}$, istotą stosunków międzyludzkich ${ }^{10}$ czy nawet składową rdzenia egzystencji ludzkiej rozumianej jako obecność: „Kto jest obecny, jest tym samym zaangażowany w polityczność"11. Skoro bowiem polityczność przynależy do esencji człowieczeństwa, wpisuje się w „źródłowość” bycia człowiekiem, to przynależy do kategorii ,rzeczy pierwszych" — przyczyn prymordialnych (causae primordiales), które zgodnie z wykładem Jana Szkota Eriugeny konstytuują „drugą formę natury”, składającą się z idei („Bożych Idei”) będących przyczyną dalszych obiektów ludzkiego poznania ${ }^{12}$. W takich ramach myślowych polityczność uzyskuje pierwszeństwo, strukturalne lub chronologiczne, przed jurydycznością (prawem i tym, co prawne), dlatego może na nią oddziaływać, czyli (współ) kształtować zjawiska prawne. Takie rozpoznanie relacji zachodzącej między politycznością a jurydycznością nasuwa przewrotne pytanie: czy możliwe jest zidentyfikowanie warunków, bez których nie jest możliwa polityczność, a które to warunki mogą być spełnione jedynie przez prawo i związane z nim fenomeny, w szczególności praktykę prawniczą lub naukę prawa?

„Przegląd Prawa i Administracji” 110, 2017, s. 41-49; M. Zirk-Sadowski, Metodologie teorii prawa a problem polityczności prawoznawstwa. Aspekt behawioralny i intensjonalny, „Przegląd Prawa i Administracji” 110, 2017, s. 51-62; R. Mańko, Nauki prawne..., s. 38-50; M. Stambulski, Polityczność w polskiej analitycznej teorii prawa. Zarys problematyki, „Archiwum Filozofii Prawa i Filozofii Społecznej” 2018, nr 3, s. 64-73; A. Sulikowski, Apolityczność w prawoznawstwie. Kryzys idei a zjawisko populizmu, „Archiwum Filozofii Prawa i Filozofii Społecznej” 2018, nr 3, s. 74-85.

9 Zob. F. Rakoczy, Autonomia prawa a problem jego polityczności, [w:] Polityka/polityczność. Granice dyskursu, red. B. Krzysztan, W. Ufel, M. Zieliński, Wrocław 2016, s. 213.

10 Zob. R. Mańko, Nauki prawne..., s. 39.

11 Zob. M. Paździora, M. Stambulski, op. cit., s. 57.

12 Jan Szkot Eriugena buduje epistemologicznie zorientowaną ontologię, to znaczy wyróżnione przez niego cztery „formy natury” należy rozumieć nie jako poziomy bytów, ale theoriae, czyli odmienne perspektywy epistemiczne, dostępne na specyficznych warunkach ludzkiemu poznaniu — por. A. Kijewska, Wstepp, [w:] Eriugena, Komentarz do Ewangelii Jana (z homilia do Prologu Ewangelii Jana), Kęty 2000, s. 16-17. 


\section{ZOON POLITIKON - REFLEKSJA 1: „ZWIERZE POLITYCZNE”}

Przyjęcie tezy o polityczności jako fundamentalnej cesze człowieka ewokuje ikonę Zoon Politikon, która została napisana przez Arystotelesa w pierwszej księdze Polityki. Na kanon tego intelektualnego obrazu politycznej istoty żywej (,,zwierzęcia") składają się dwa paragrafy z pierwszego rozdziału tej księgi: dziewiąty i dziesiąty (wedle podziału J.G. Schneidera z 1809 roku). W swoistym prologu do ikony Zoon Politikon, który można odnaleźć w paragrafie ósmym wskazanego rozdziału, Stagiryta ukazuje związek wegetatywnego wymiaru bytu człowieka z jego byciem-w-państwie:

Pełna w końcu wspólnota, stworzona z większej ilości gmin wiejskich, która niejako już osiągnęła kres wszechstronnej samowystarczalności, jest państwem; powstaje ono dla umożliwienia życia, a istnieje, aby życie było dobre ${ }^{13}$.

Człowiek rzeczywiście może być pojmowany jako „Zwierzę polityczne”, ponieważ polityczność pozostaje w związku z wymiarem, który człowiek współdzieli z innymi zwierzętami, to jest z wymiarem biologicznego trwania i reprodukcji. Osobniki Homo sapiens sapiens w warunkach presji środowiskowej, zagrażającej trwałości życia biologicznego (zoe), muszą rozpoznać konieczność, „aby się łączyły ze sobą istoty, które bez siebie istnieć nie mogą, a więc żeńska i męska w celu płodzenia"14. W ten sposób powstają naturalne i konieczne stowarzyszenia osobników gatunku ludzkiego, czyli najpierw dom (oikia), resp. rodzina, następnie gmina wiejska, a w końcu państwo (polis) ${ }^{15}$.

Po tym prologu Arystoteles wprowadza swoją konstrukcję antropologiczną człowieka jako istoty politycznej:

9. Okazuje się z tego, że państwo należy do tworów natury, że człowiek jest z natury stworzony do życia w państwie, taki zaś, który z natury, a nie przez przypadek żyje poza państwem, jest albo nędznikiem, albo nadludzką istotą, jak ten, którego piętnuje Homer, jako „człowieka bez rodu, bez prawa, bez [własnego - M.R.] ogniska”. Kto bowiem z natury swojej jest taki, równocześnie i wojny namiętnie pożąda, będąc odosobniony, jak ten kamień wyłączony w grze w kości ${ }^{16}$.

Jedynie nędznik lub bóg mogą być wyłączeni poza sferę polityki, ale natura człowieka przymusza go, aby żył w państwie i tworzył wspólnotę polityczną, gdyż nie jest samow y starczalny. Człowiek nie jest w stanie zachować swojego życia, będąc w odosobnieniu, dlatego wedle Arystotelesa jest „istotą państwo-

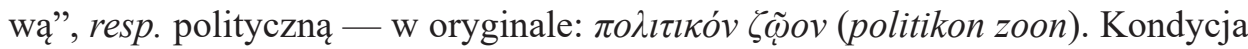
człowieka wymaga wchodzenia w identyfikację z innymi osobnikami Homo sapiens sapiens $\mathrm{w}$ celu uwspólniania wysiłków ukierunkowanych na zachowanie

\footnotetext{
13 Arystoteles, Polityka, Warszawa 2012, s. 27; wyróżnienia w tekście - M.R.

14 Zob. ibidem, s. 25.

15 Zob. ibidem, s. 25-27.

16 Ibidem, s. 27; wyróżnienia w tekście - M.R.
} 
życia. Człowiek musi odnaleźć swój „,ród”, „prawo” i „ognisko”, w tym właśnie celu natura wyposażyła go w język, czyli kluczową cechę „zwierzęcia politycznego", którą Arystoteles uchwycił w paragrafie dziesiątym pierwszego rozdziału księgi pierwszej Polityki.

W tym miejscu potrzebne jest jednak cięcie, które daje szansę na pogłębienie refleksji nad politycznością człowieka i jej zakładaną prymarnością. Usuwając poza obszar prowadzonych rozważań kwestię obecności w arystotelesowskiej koncepcji polityki nieuchronnego antagonizmu, co byłoby kluczowe do ustalenia identyczności pojęć polityczności u Stagiryty i C. Schmitta, należy odnotować kluczową zbieżność - sfera życia wspólnotowego ujawnia się w figurze Zoon Politikon jako fundamentalna dla bycia-człowiekiem, a życie polityczne (bios politikos) zespaja się z życiem wegetatywnym $\left(z o e^{17}\right) \mathrm{w}$ tym sensie, że wejście w „samowystarczalną” wspólnotę polityczną z właściwego jednostce „odosobnienia” jest warunkiem trwania życia jako takiego, stąd stwierdzenie, że to państwo „umożliwia życie". Arystoteles wyprowadza z tych ustaleń daleko idące konsekwencje dla swojej antropologii:

Okazuje się tedy, że państwo jest tworem natury i że jest pierwej od jednostki, bo jeśli każdy z osobna nie jest samowystarczalny, to znajduje się w tym samym stosunku [do państwa — M.R.], co i inne część do jakiejś całości. Kto zaś nie potrafi żyć we wspólnocie albo jej wcale nie potrzebuje, będąc samowystarczalny, bynajmniej nie jest członem państwa, a zatem jest albo zwierzęciem, albo bogiem ${ }^{18}$.

Polityczność, rozumiana minimalistycznie jako wspólnotowy wymiar życia ludzkiego (bios), zostaje finalnie uznana za wyprzedzającą w porządku strukturalnym samą jednostkę, a zatem za coś prymarnego. Myśl Arystotelesa tutaj się jednak nie wyczerpuje - co prawda jednostka w swojej nie-samowystarczalności jest zaledwie członem państwa, to aby w nim zaistnieć, musi nabyć pewne umiejętności, bez których nie będzie „potrafiła żyć we wspólnocie” i pozostanie tylko „zwierzęciem”. Co musi się wydarzyć, aby jednostka „potrafiła” żyć w sferze politycznej (Arystoteles) i współtworzyć wspólnotę „przyjaciół” w opozycji do wspólnoty „wrogów” (C. Schmitt)?

Ikona Zoon Politikon odsłania prymarne warunki: osobnik Homo sapiens sapiens, którego udziałem jest zoe, przede wszystkim musi rozpoznać swoje odosobnienie w środowisku, swoją odrębność w nim i swoje potrzeby, a następnie skonstatować swoją nie-samowystarczalność dla zachowania i uformowa-

17 Przyjmuję pogląd Giorgia Agambena, że greckie słowo zoe (dzoē) oznacza życie jako właściwość wszystkich ożywionych bytów, które określam także jako „życie wegetatywne” (od typu duszy wyróżnionej przez Arystotelesa), natomiast słowo bios odnosi się do życia jako formy lub sposobu życia właściwego jednostce lub grupie. W wyrażeniu Zoon Politikon przymiotnika „polityczne" nie należy rozumieć jako atrybutu bytu ożywionego jako takiego, należącego do płaszczyzny zoe, ale jako differentia specifica, tworzącą kwalifikowaną formę życia wegetatywnego (zoe), czyli właśnie bios — zob. idem, Homo sacer. Suwerenna władza i nagie życie, Warszawa 2008, s. 9-11.

18 Arystoteles, op. cit., s. 28; wyróżnienia w tekście — M.R. 
nia własnego życia wegetatywnego, czyli wejścia w życie rozumiane jako bios. Innymi słowy osobnik Homo sapiens sapiens potrzebuje doświadczyć własnej podmiotowości, bez której nie jest możliwe nawet zidentyfikowanie granic swojego ciała w strumieniu wrażeń płynących ze środowiska zewnętrznego, a co dopiero zidentyfikowanie ,przyjaciela” lub „wroga”. Życie polityczne (bios politikos), czyli życie we wspólnocie politycznej, resp. państwie, wynika - wedle antycznego wykładu Arystotelesa - z natury człowieka, a nie zwierzęcia. Organizm żywy, który ma cechy gatunku Homo sapiens sapiens, wegetujący na płaszczyźnie zoe, musi wejść na ścieżkę upodmiotowienia, aby zrealizować swoją naturalną potencję istoty politycznej, której udziałem jest życie człowiecze (bios). To właśnie tymi zrębami podmiotowości, które warunkują polityczność jako taką, są w ikonie Zoon Politikon przywołane przez Arystotelesa za Nestorem, bohaterem Iliady Homera, „ród”, „prawo” i „ognisko”19. Bez nich człowiek żyje bowiem poza państwem, wbrew swojej naturze, a zatem jest albo „nędznikiem”, czyli „zwierzęciem”, albo „bogiem”.

\section{ZOON POLITIKON - REFLEKSJA 2: „ZWIERZĘ MÓWIĄCE”}

Cięcie przeprowadzone pomiędzy paragrafami dziewiątym i dziesiątym pierwszego rozdziału księgi pierwszej Polityki eksponuje rozpoznany w poprzedniej części warunek polityczności. W drugiej warstwie ikony Zoon Politikon znajduje się bowiem antropologiczna wskazówka, jak człowiek może zrealizować zawarte w swojej naturze przynaglenie do życia w sferze polityki, resp. polityczności — bios politikos. Jak ukazała analiza paragrafu dziewiątego i prologu (czyli fragmentu paragrafu ósmego) do ikony Zoon Politkon, jest to nawet konieczność, wynikająca z nie-samowystarczalności osobnika Homo sapiens sapiens. Polityczność jako cecha człowieka może być odczytywana w kontekście teleologiczności metafizyki Arystotelesa jako potencja, którą człowiek powinien realizować, aby żyć zgodnie ze swoją naturą ${ }^{20}$, jednakże przeprowadzona refleksja wskazuje na mocniejszy związek bios politikos z zoe, to znaczy życie polityczne człowieka jest nie tylko potrzebne do jego wzrostu ku właściwej sobie, naturalnej celowości, ale jest wręcz warunkiem „ustanowienia” i zachowania życia jako takiego.

Ten ścisły związek, ukazany przez Arystotelesa w ścieżce ewolucji instytucji życia wspólnotowego ludzi: od rodziny do państwa, nie przekreśla możliwości rozpoznania radykalnej różnicy między sferą domu (oikia) a państwa (polis), polegającej na pewnej nadwyżce występującej w sferze polityczności. W domenie polityki nie chodzi bowiem tylko o zachowanie życia wegetatywnego (zoe), ale

19 Zob. ibidem, s. 27, przyp. 11.

20 Zob. np. M. Gajek, Człowiek jako obywatel w myśli Arystotelesa, „Zoon Politikon” 2010, nr 1, s. 40. 
nadanie osobnikom gatunku ludzkiego nowej formy egzystencji — bios politikos - która ustanowi sferę życia publicznego w opozycji do życia prywatnego i sfery społecznej. Podążając za $\mathrm{H}$. Arendt ${ }^{21}$, należy dostrzec różnicę między społeczną cechą człowieka (człowiek jako animal socialis), która polega na stowarzyszaniu się osobników Homo sapiens sapiens tylko w celu zachowania życia wegetatywnego, a cechą polityczności człowieka (człowiek jako zoon politikon), która polega na wejściu w przestrzeń umożliwiającą formy działania inne niż jedynie takie, których celem jest zachowanie życia wegetatywnego („aby życie było dobre”). Nie można przy tym jednak zapomnieć, że wedle wykładu Arystotelesa zawartego w pierwszej księdze Polityki sfera polityki, resp. państwo, przejmuje funkcję umożliwiania i utrwalania ludzkiego życia wegetatywnego - w tym sensie bios pochłania zoe czy raczej bios buduje się na zoe. Wydaje się to dostrzegać także H. Arendt, kiedy powołując się na Fustela de Coulanges, stwierdza, że antyczna filozofia polityki uwzględniała w swoich koncepcjach fakt historyczny pochłonięcia (,zniszczenia”) przez polis wcześniejszych form wspólnotowości opartych na pokrewieństwie: phratria i phyle $e^{22}$.

W dalszym swym wywodzie, to jest w paragrafie dziesiątym, Stagiryta wyjaśnia, jak „zwierzę” należące do płaszczyzny zoe może przeobrazić się w „zwierzę polityczne", które utrwala i rozwija swoje istnienie w bios (politikos). Arystoteles raz jeszcze odwołuje się do natury człowieka i wydobywa z niej cechę językowości:

10. Że człowiek jest istotą stworzoną do życia w państwie więcej niż pszczoła lub jakiekolwiek zwierzę żyjące w stadzie, to jasną jest rzeczą. Natura bowiem, jak powiadamy, nic nie czyni bez celu. Otóż człowiek jedyny z istot żyjących obdarzony jest mową. Głos jest oznaką radości i bólu, dlatego posiadają go i inne istoty (rozwój ich posunął się bowiem tak daleko, że mają zdolność odczuwania bólu i radości, tudzież wyrażania tego między sobą). Ale mowa służy do określania tego, co pożyteczne czy szkodliwe, jak również i tego, co sprawiedliwe czy też niesprawiedliwe ${ }^{23}$.

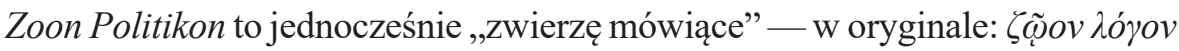
É $\chi \omega v(Z o o n$ Logon Echon). Istota żywa, aby być zdolna do mówienia, musi operować relacją separacji, to znaczy musi być w stanie odróżnić to, co nazwane (obiekt), od tego, co nazywa (znak), jednocześnie wykonując rolę tego, który nazywa (mówiący). Tym sposobem Zoon Logon Echon ukazuje się jako podmiot, gdyż człowieczą zdolność mówienia musi poprzedzać proces odseparowania się od zbioru obiektów, które można nazywać. Osobnik Homo sapiens sapiens jako „zwierzę mówiące” musi zatem identyfikować granice własnego ciała w opozycji do innych obiektów.

Analizując drugą warstwę ikony Zoon Politikon, można pójść nawet dalej „zwierzę mówiące” musi mieć choćby zarys granic własnego Ja, albowiem opano-

21 Zob. H. Arendt, Kondycja ludzka, Warszawa 2010, s. 39-100.

22 Zob. ibidem, s. 43, przyp. 6.

23 Arystoteles, op. cit., s. 27; wyróżnienia w tekście - M.R. 
wanie mowy związane jest — jak wykłada to Arystoteles — z możnością określania „tego, co pożyteczne czy szkodliwe”. Mówiący posiadł zatem przynajmniej umiejętność rozpoznawania swoich potrzeb, inaczej nie mógłby wypowiedzieć tego, co jest dla niego pożyteczne lub szkodliwe. Mowa, służąc w dalszej kolejności do określenia „tego, co sprawiedliwe czy też niesprawiedliwe”, zakłada możność dokonywania własnych sądów moralnych, a zatem jeszcze wyższą organizację podmiotu ${ }^{24}$.

Reasumując, trzeba wskazać, że prowadzona refleksja ujawnia, że Zoon Logon Echon jest figurą stojącą w miejscu podmiotu. Językowość człowieka to cecha, która umożliwia wejście istoty żywej z płaszczyzny zoe do sfery polityki, resp. polityczności, w której „zwierzę” przeobrazi się w Zoon Politikon, a jego życie wegetatywne (zoe) zostanie nie tylko zabezpieczone przez możliwość kooperacji z innymi „zwierzętami politycznymi” (,istotami, które bez siebie istnieć nie mogą"), ale przede wszystkim zostanie uformowane w życie człowiecze (bios). Skoro posługiwanie się językiem umożliwia politykę, resp. polityczność, Zoon Politikon staje się bowiem za sprawą Zoon Logon Echon, to filozofia polityczna Arystotelesa ujawnia warunek polityczności in genere: jest nim wyłonienie się podmiotowości człowieka. W świetle tych ustaleń pytanie otwierające prowadzoną analizę przekształca się w pytanie o genealogię podmiotu ludzkiego: w jaki sposób wyłania się pomiot ludzki i czy prawo lub jego zjawiska mają w tym swój udział? Jest to pytanie par excellence antropologiczne, albowiem - jak zauważył Pierre Legendre - zawartość semantyczna pojęcia antropologii (gr. $\ddot{\alpha} v \theta \rho \omega \pi \circ \varsigma$ i $\lambda o ́ \gamma o \varsigma$ ) przywołuje związek człowieka z logo sem ${ }^{25}$, a więc ewokuje figurę Zoon Logon Echon.

\section{PSYCHODYNAMIKA UPODMIOTOWIENIA „ZWIERZĘCIA MÓWIĄCEGO”}

Francuski kanonista, romanista, historyk administracji i filozof ${ }^{26}$, sięgając do arystotelesowskiej ikony Zoon Politikon, znajduje w niej splątanie trzech typowo

${ }^{24}$ Notabene analogiczną antropologię znajdujemy w tradycji judeochrześcijańskiej w scenie zapisanej w rozdziale 2 Księgi Rodzaju, w którym dopełnieniem antropogenezy pierwszego człowieka Adama jest czynność nadawania nazw stworzeniom ( $\operatorname{Rdz} 2,18-20)$. To poprzez mówienie pierwszy człowiek odkrywa swoją samotność w świecie „istot żywych”, a zatem separuje się względem stworzenia w środowisku swojej życia, dostrzegając, że nie znajduje tam „pomocy dla siebie” w zadaniu ,uprawiania i doglądania” ogrodu Eden, a więc w tym, co zgodnie z narracją o stworzeniu świata jest wyłącznie ludzkie. Wszystkie cytaty z Pisma Świętego za: Biblia Tysiąclecia, Poznań 2003, https://biblia.deon.pl/ (dostęp: 2.04.2020).

25 Zob. P. Legendre, Antropologia dogmatyczna. Definicja pojęcia, „Kronos” 2010, nr 3, s. 19.

26 Jak pokazuje Hubert Izdebski, który miał okazję studiować u Pierre'a Legendre'a, charakterystyka profilu intelektualnego tego humanisty jest bardzo trudna, gdyż lokuje się w nurcie badań interdyscyplinarnych, a nawet postdyscyplinarnych — zob. H. Izdebski, Pierre Legendre — kanonista, romanista, historyk administracji i...?, „Kronos” 2010, nr 3, s. 38. 
ludzkich obszarów: biologicznego, społecznego i psychologicznego (nieświadomego), w którym to przemieszaniu ukryte są zarówno tajemnica ufundowania podmiot ludzkiego, jak i wskazówka, że to w psychoanalizie należy poszukiwać klucza do jej rozwiązania ${ }^{27}$. W tym wysiłku P. Legendre znalazł wsparcie w koncepcjach swojego nauczyciela i przyjaciela ${ }^{28}$ — Jacques'a Lacana — który głosząc hasło ,powrotu do Freuda"29, czerpał jednocześnie z ustaleń jego rówieśnika Ferdinanda de Saussure'a i zaproponował przeformułowanie zastanej psychoanalizy w „lingwistykę mówienia”"30, czyli dyscyplinę adekwatną dla Zoon Logon Echon.

Poprzez wprowadzenie do teorii psychoanalitycznej pojęcia „znaku” jako nowego pojęcia fundamentalnego ${ }^{31} \mathrm{~J}$. Lacan uruchomił refleksję nad podmiotowością ufundowaną na językowości człowieka. Koncepcja znaku (signe) podległa innowacyjnemu przekształceniu - o ile w językoznawstwie F. de Saussure'a znak jest „bytem psychicznym o dwóch obliczach”, łączy bowiem w sobie „obraz akustyczny” (image acoustique) i „pojęcie” (concept), czyli odpowiednio znaczące (signifiant) i znaczone (signifié), przy czym znaczone dominuje nad znaczącym $^{32}$, o tyle w ujęciu lacanowskim pierwszeństwo zostaje przyznane znaczącemu („S”). W efekcie do schematu F. de Saussure'a zostaje wprowadzona gruba kreska sygnalizująca „ciągłe ślizganie się znaczonego pod znaczącym”33. Owa językoznawcza herezja nie służyła J. Lacanowi do konstruowania nowej lingwistyki, ale do wydobywania źródłowych wglądów S. Freuda za pomocą terminologii F. de Saussure'a ${ }^{34}$. Autor Écrits doszedł do wniosku, że S. Freud, w pewnym sensie antycypując odkrycie F. de Saussure'a, wypracował pojęcie nieświadomości jako łańcucha znaczących (chaîne de signifiants), który utrwalony i powtarzany stara się wniknąć w mowę potoczną i w refleksję, którą owa mowa wzbudza ${ }^{35}$.

27 Zob. P. Legendre, Inny wymiar prawa, „Kronos” 2010, nr 3, s. 10-13.

${ }^{28}$ Zob. H. Izdebski, op. cit., s. 38-39; T. Chauvin, Prawo jako dyskurs o życiu - antropologia dogmatyczna Pierre'a Legendre'a, „Archiwum Filozofii Prawa i Filozofii Społecznej” 2014, nr 1, s. 6; W. Rymkiewicz, Edytorial, „Kronos” 2020, nr 3, s. 3.

29 Jak zauważa Alina Henzel-Korzeniowska, zadając pytanie, czy lektura Lacana jest koniecznością, czy raczej fanaberią: „Entuzjazm i wrogość wobec lektury Lacana nie byłby tak duży, gdyby nie fakt, że Lacan zmusza czytelnika do tego, aby wracał do tekstów Freuda" - eadem, Teoria Jacques'a Lacana i jej pożytek dla doświadczenia psychoanalitycznego, „Edukacja Etyczna” 2013, nr 6, s. 5.

30 J. Lacan, Écrits, Paris 1966, s. 799.

31 Zob. R. Meyer-Kalkus, Jacques Lacan: Psychoanaliza jako lingwistyka mówienia, „Teksty Drugie" 1998, nr 1-2, s. 6.

32 Zob. F. de Saussure, Kurs językoznawstwa ogólnego, Warszawa 1991, s. 90-91, w szczególności zaprezentowane tam schematy, w których znaczone (pojęcie) jest umieszczone nad znaczącym (obrazem akustycznym) - identycznie w schematach na s. 138-141.

33 J. Lacan, op. cit., s. 502.

34 Zob. R. Meyer-Kalkus, op. cit., s. 8.

35 Zob. J. Lacan, op. cit., s. 799. Nieświadomość — królewski przedmiot psychoanalizy — okazuje się tworem ustrukturyzowanym niczym mówienie (parole). W teorii Jacques'a Lacana mowa jest warunkiem nieświadomości, która w konsekwencji może zaistnieć jedynie u bytu mó- 
Mimo że w obszarze nieświadomych warstw psychiki nie jest możliwe ustalenie żadnego definitywnego i stałego znaczenia ${ }^{36}$, jednostka dąży jednak do, choćby częściowego, jej wypowiedzenia, próbuje bowiem odnaleźć i objaśnić sobie samą siebie. Zoon Logon Echon, odkrywając własną językowość, dąży do objaśnienia zakrytych znaczonych własnych znaczących poprzez inne znaczące, ponieważ jedynie poprzez mówienie człowiek może próbować porozumieć się co do swoich myśli, pragnień i wyobrażeń. W konsekwencji każde znaczące, wyrwane lub wyrywające się w mowie z dowolnego, jednostkowego łańcucha znaczących, czyli nieświadomości, okazuje się reprezentacją niczego innego niż p o d mi ot (sujet). $\mathrm{Z}$ elegancją ujmuje to wyciosana przez J. Lacana definicja znaczącego, zgodnie z którą „,znaczącym jest to, co przedstawia podmiot dla innego znaczącego"37.

Nie ma innej formy wyłaniania się podmiotu niż poprzez znaczące. Teoria J. Lacana, fundując psychoanalizę jako „lingwistykę mówienia”, potwierdza zatem, że figura Zoon Logon Echon wypełnia miejsce podmiotu, artykułuje bowiem językowość człowieka jako ścieżkę ludzkiego upodmiotowienia. Którędy jednak biegnie ta ścieżka? Z przywołanej lacanowskiej lekcji wiadomo już, że podmiot wyłania się z mówienia, które obejmuje znaczące reprezentujące jednostkę wobec innego znaczącego. Zoon Logon Echon dąży do poznania samego siebie, co jest możliwe jedynie poprzez język, chce bowiem ,podejść do samego siebie, aby stworzyć własny obraz"38, na co język pozwala, ponieważ poprzez nazywanie otwiera drogę do reifikowania, a więc tworzenia iluzorycznych przedmiotów.

W ontogenezie człowieka pierwszym krokiem na ścieżce upodmiotowienia jest zawiązanie się konstrukcji ego (la moi), co zdaniem J. Lacana zachodzi w tak zwanym stadium lustra (stade de miroir) ${ }^{39}$. Pomiędzy 6. a 18. miesiącem życia, kiedy dziecko początkowo dysponuje jedynie obrazem „ciała pokawałkowanego", gdyż nie wypracowało jeszcze właściwej gatunkowi ludzkiemu koordynacji ruchowej, a poprzez wyraźnie uprzywilejowany u Homo sapiens sapiens zmysł

wiącego — zob. idem, Radiophonie, [w:] idem, Autres écrits, Paris 2001, s. 406; idem, Télévision, [w:] idem, Autres écrits..., s. 511.

36 Łączenie znaczącego i znaczonego jest ciągłym ślizganiem się tego drugiego pod tym pierwszym. J. Lacan twierdził, że w nieświadomym znaczący nie pozycjonuje się względem znaczonego, ale wobec innych znaczących, stąd nonsensowność nieświadomości, czyli niemożność jej pełnego i definitywnego wypowiedzenia. Symptom może utracić swoje dawne asocjacyjne relacje i wejść w nowe, afirmując się w nowych konstruktach mowy (lapsusach, dowcipach, sformułowaniach bez sensu, czynnościach pomyłkowych) lub tworach językopodobnych (marzeniach sennych) — zob. R. Meyer-Kalkus, op. cit., s. 12; o lingwistycznie objaśnianej nonsensowności nieświadomego w ujęciu J. Lacana zob. także G. Michalik, Podmiot znikajacy - kwestia podmiotowości w psychoanalizie Jacques'a Lacana, „Analiza i Egzystencja” 2018, nr 41, s. 85.

37 J. Lacan, Écrits..., s. 819.

38 H. Lang, Język i nieświadomość. Podstawy teorii psychoanalitycznej Jacques'a Lacana, Gdańsk 2005, s. 121.

39 Zob. J. Lacan, Stadium zwierciadła jako czynnik kształtujący funkcję Ja w świetle doświadczenia psychoanalitycznego. Referat na XVI Międzynarodowym Kongresie Psychoanalitycznym, Zurich, 17 lipca 1949, „Psychoterapia” 1987, nr 4, s. 5-9. 
wzroku doświadczało jedynie poszczególnych części własnego ciała (na przykład kończyn), osesek po raz pierwszy widzi własne ciało w lustrze i spostrzega siebie. Jest to wydarzenie euforyczne, albowiem percypowana wzrokowo jedność własnych ruchów stoi w jaskrawym kontraście do wcześniejszych doświadczeń rozbicia i nieporadności ${ }^{40}$. Radość generowana przez postrzeganie imago ciała „wyraża w tej egzemplarycznej sytuacji symboliczną matrycę, która umożliwia wykształcenie się pierwszej formy Ja" ${ }^{41}$, to znaczy Ja (la moi) idealnego. Dziecko, percypując lustrzany obraz siebie, po raz pierwszy wyobraża sobie siebie jako integralną całość pomimo dalszego braku na poziomie realnym właściwej koordynacji ruchowej. Fantazjuje jednak o sobie takim, jakim pragnie być, a zatem jego pierwsze Ja idealne jest jednocześnie Ja wyobrażeni ow ym, które J. Lacan określa właśnie wyrażeniem ego (la moi).

Sytuacja lustra, mająca miejsce już w pierwszych tygodniach życia osobnika z gatunku Homo sapiens sapiens, jest paradygmatycznym uchwyceniem własnej jednostkowości za pomocą obrazu, które jednocześnie jest „pułapką identyfikacji”, albowiem uruchomi kaskadę kolejnych fantazmatów domagających się swojej nieustannej weryfikacji. Obraz, z którym dziecko się identyfikuje, wprowadza dialektycznie pierwsze doświadczenie alienacji, ponieważ jako coś, co należy do świata zewnętrznego (Umwelt), lustrzane odbicie ciała nie może być utożsamione z własnym Ja (le je), które przynależy do świata wewnętrznego (Innen$\left.w_{e l t}\right)^{42}$. Wyobrażenie cielesnej jedności, czyli pierwsza postać ego, paradoksalnie przez ekskluzywne ulokowanie imago, czyli przedmiotu identyfikacji, prowadzi do wyobcowania podmiotu. Konsekwencją psychicznej mechaniki stadium lustra jest przesunięcie kwestii podmiotu w obszar intersubiektywności. To do Innego (grand Autre, A) będzie odtąd kierowane roszczenie o odkrycie własnej podmiotowości, czego początkowymi przejawami są interpersonalne zachowania dziecka mające cechy tranzytywizmu, czyli projektowania własnych stanów psychicznych na innych oraz przyswajanie cudzych stanów psychicznych jako własnych na podstawie zaobserwowanych ekspresji emocjonalnych i zachowań (na przykład kiedy dziecko na widok płaczu innego dziecka także zaczyna płakać albo bijąc inne dziecko, samo wylewnie lamentuje, że jest bite).

Pierwotna alienacja stadium lustra ukazuje odrębność pomiotu (sujet, S) od ego (le moi), które jest jedynie fantazmatem jednostki na ścieżce do własnej podmiotowości. Kolejny krok zostanie wykonany w stronę zewnętrznego świata, gdzie jednostka poszukuje Innego (A), aby z jego pomocą objaśnić sobie samą

40, ,Świadczy o tym mimika towarzysząca temu odkrywczemu przeżyciu i zachwyt pojawiający się w momencie, w którym niemowlę zauważy, że ruchy obserwowane przez nie w lustrze odpowiadają jego własnemu. [...] Niemałe znaczenie dla antropologii ma fakt, że szympans, w przeciwieństwie do zafrapowanego ludzkiego oseska, odchodzi w tej sytuacji od lustra, nie wykazując nim dalszego zainteresowania, jak tylko spostrzega, że pojawiający się w nim obraz pozbawiony jest realnej treści" - H. Lang, op. cit., s. 75-76.

41 J. Lacan, Stadium zwierciadła ..., s. 6.

42 Zob. ibidem, s. 7. 
siebie. Czy go jednak znajduje? Jacques Lacan dostrzega tutaj wszechobecność Wyobrażeniowego ${ }^{43}$, to znaczy tak, jak dla jednostki jest ona sama dostępna jedynie jako Ja wyobrażeniowe (ego), tak Inny (A) jest dla niej dostępny jedynie jako pewne wyobrażenie innego (autre, a'). Bezpośrednia rozmowa dwóch podmiotów nie jest zatem w ogóle możliwa, albowiem w relację S-A interferują dwie imaginacje. Czy zatem w ogóle możliwe jest zrealizowanie skierowanego do Innego (A) roszczenia o odkrycie własnej podmiotowości? Jeżeli ze stadium lustra niemowlęcy Homo sapiens sapiens wychodzi na ścieżkę poszukiwania, czy wręcz łaknienia, własnej podmiotowości, a pierwsze doświadczenie alienacji względem imago, z którym osesek się jednocześnie identyfikuje, naznacza kształtującą się psychikę i jej poszukiwania stygmatem eksterioryzacji, to w jaki sposób może on odkryć własną podmiotowość na zewnątrz siebie, w Umwelt, w domenie Innego (grand Autre, A), skoro jest mu dany tylko jego obraz - Wyobrażeniowy inny (a')? Aby znaleźć odpowiedź na to pytanie, należy sięgnąć do lacanowskiego grafu $^{44}$ (schemat 1$)$, który można zinterpretować jako topologiczne przedstawienie człowieczej podmiotogenezy.

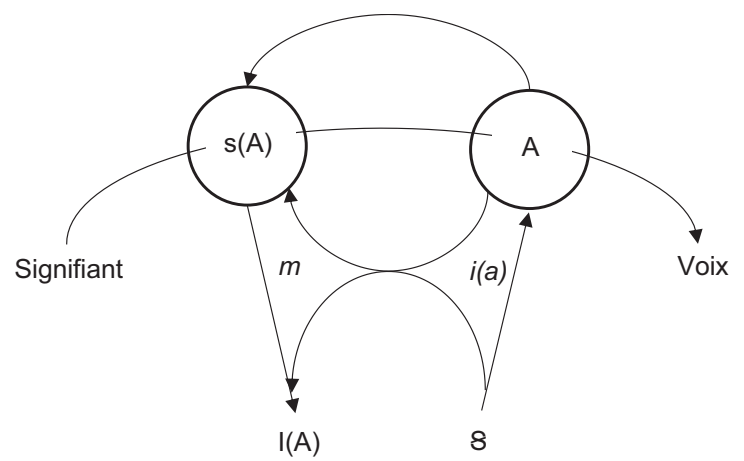

Schemat 1. Graf pragnienia J. Lacana jako model podmiotogenezy

Źródło: opracowanie własne.

43 Jednym z narzędzi teoretycznych i psychoanalitycznych J. Lacana jest triada rejestrów, w których funkcjonuje każda ludzka jednostka, to jest Wyobrażeniowego (świadome lub nieświadome obrazy, z którymi jednostka się identyfikuje), Symbolicznego (autonomiczny i zewnętrzny w stosunku do jednostki zbiór znaczących, obszar mowy) i Realnego (to, co nie jest możliwe do wypowiedzenia i wyobrażenia, a zatem obszar nakreślony poprzez negację dwóch poprzednich rejestrów, sfera traumy) - zob. idem, Imiona-Ojca, Warszawa 2013, s. 15. W toku dalszej refleksji znaczenie tych pojęć zostanie szerzej odsłonięte.

${ }^{44}$ Graf ten prezentuje i poddaje analizie Jacek Schodowski, czytając Subversion du sujet et dialectique du désir dans l'inconscient freudien J. Lacana — zob. idem, Podmiot pragnienia. Czytając Subversion du sujet et dialectique du désir, „Kronos” 2010, nr 1, s. 81-82; por. H. Lang, op. cit., s. 312-316. Graf pragnienia stopniowo ewoluował w kolejnych seminaryjnych odsłonach teorii J. Lacana, jednakże ze względu na ograniczone rozmiary prowadzonej refleksji jako topologię podmiotogenezy wybrano stadium pośrednie, pozwalające na unaocznienie procesu konstruowania się podmiotu bez wchodzenia w szczegóły terapeutycznego oddziaływania Innego-analityka na podmiot-pacjenta („leczenia mową”). 
Proces upodmiotowienia zaczyna się dla jednostki od „wrzucenia w język”45. Zoon Logon Echon, odkrywając językowość, właśnie przy jej pomocy będzie próbował odnaleźć znaczące, które pozwolą mu na opisanie siebie, czyli skonstruowanie własnej podmiotowości. Ponieważ nieświadome ustrukturyzowane jest jak mowa, to w językowości jednostka będzie dążyła do uchwycenia sensu choćby dla cząstki swojego psychicznego bytu, reszta pozostanie zasłonięta jako niemożliwe do wyrażenia poprzez znaki mowy pragnieniowe Realne. Wrzucona w język jednostka jest jednak wobec niego wyalienowana i pozostaje podmiotem podzielonym (sujet barré - symbolizowane przez przekreślone S: \$), który nie potrafi wyrazić swojego psychicznego jestestwa w łańcuchu znaczących. Podmiot podzielony w procesie stawania się musi napotkać Innego (Autre, A), który poprzedza go w językowym funkcjonowaniu, operując zestawami znaków. W koncepcji J. Lacana jest to tak zwany point de capiton, to jest punkt przecięcia się pionowej linii wznoszącej symbolizującej proces upodmiotowiania się $-\mathrm{z}$ linią poziomą, biegnącą od lewej do prawej, symbolizującej mowę w jej czasowym wymiarze.

Point de capiton jest kluczowym momentem, w którym podmiot podzielony przez językowość Innego (A) przeobraża się w podmiot właściwy — podmiot symboliczny — ponieważ w polu Innego (A) odkrywa ,skarbnicę znaczących”46, które porywają jednostkę i konstytuują ją w rejestrze Symbolicznego. Zbiór znaków-symboli staje się dostępny dla $\mathrm{S}$, pod warunkiem że opanuje posługiwanie się kodem wyznaczonym przez Innego (A). Przejście przez kodowanie w znaczące, które Inny (A) przeprowadza na podmiocie podzielonym S, zostaje utrwalone w punktacji (la ponctuation), którą symbolizuje $s(\mathrm{~A})$. Jest to funkcja Innego, pole, gdzie ,znaczenie kończy jako gotowy produkt”47, to jest konkretna struktura mowy, która odtąd będzie strukturyzowała podmiotowość jednostki. Struktura ta została przedstawiona na grafie jako zakończenie poziomego wektora znaczących, czyli miejsce, gdzie wyłania się głos (voix) będący produktem operacji znaczeniowej przeprowadzonej na tym, co tego znaczenia było pozbawione, a co na poziom Symbolicznego wprowadził wznoszący się od punktu $\mathrm{S}$ wektor podmiotowości ${ }^{48}$.

Opadając, pionowa linia wektora podmiotowości kończy swój bieg w punkcie I(A), który symbolizuje identyfikację jednostki z cząstką Innego (A) w tym, co Symboliczne. Jest to „idealność dana przez Innego” (the ideal given by the Other $)^{49}$, odpowiadająca freudowskiemu Ideałowi Ja (Ich-Ideal), którego w żadnym wypadku nie należy utożsamiać z Ja idealnym (le moi). Ideał Ja nie należy bowiem do Wyobrażeniowego, nie jest obrazem-iluzją, w który jednostka wpatruje się, poszukując siebie i snując fantazmat własnego Ja, ale strukturą Symboliczną,

45 Jak zauważa J. Schodowski, analogiczny moment znajdujemy w filozofii człowieka M. Heideggera i H.G. Gadamera — zob. idem, op. cit., s. 81.

46 J. Lacan, Écrits..., s. 806.

47 Ibidem.

48 Zob. J. Schodowski, op. cit., s. 82.

49 B. Fink, Lacan to the Letter. Reading Écrits Closely, Minneapolis 2004, s. 108. 
to znaczy zestawem znaczących, w który Inny (A) wyposażył jednostkę, przekształcając ją tym samym w podmiot. Jak stwierdza J. Lacan: „Ich-Ideal, ideał ja, to inny mówiący, inny jako mający ze mną relację symboliczną" 50 .

Wyobrażeniowe Ja idealne (le moi) także jest obecne w modelu podmiotogenezy w postaci symbolu $m$ (moi). Wyraża ono wcześniej przedstawioną identyfikację wyobrażeniową z imago, której mechanizm uruchamia się w stadium lustra. Analizowany graf prezentuje wynik ewolucji tego elementu psychicznego w teorii J. Lacana, który na etapie Seminarium VIII (1960 roku) doszedł do wniosku, że samo spostrzeżenie odbicia w lustrze nie może mieć mocy formowania Ja (moi), lecz do tego potrzebny jest jeszcze trzeci element — oprócz jednostki (oseska) i jego zwierciadlanego imago - aprobata Innego (rodzica) ${ }^{51}$. W konsekwencji tej zmiany koncepcyjnej dochodzi do ustalenia hegemonii Symbolicznego nad Wyobrażeniowym - spójność podmiotu jest warunkowa nie przez sam mechanizm identyfikacji wyobrażeniowej stadium lustra, lecz przez zewnętrzną wobec jednostki instancję Innego, która musi „ratyfikować” imago (Wyobrażeniowe) uspójniające „raczkujący” protopodmiot. Dzieje się to w miejscu i(a), symbolizującym poziom identyfikacji wyobrażeniowej, w której wyłania się freudowskie Ja idealne $\left(\right.$ Ideal-Ich) ${ }^{52}$, na którym J. Lacan wzorował swoje la moi. Jak wynika ze schematu 1, identyfikacja wyobrażeniowa $i(a)$ jest całkowicie podporządkowana Innemu (A), który reprezentuje porządek Symboliczny, i dąży ona do Ideału Ja: I(A), a zatem proces identyfikacji należy odczytywać jako internalizację symboli-znaczących, które pochodzą od Innego (A) i pozwalają jednostce odkryć własną podmiotowość 53 .

W tym miejscu niezbędne jest drugie cięcie, które przesunie kwestię dalszej ewolucji analizowanego grafu w lacanowskie wyjaśnienie pragnienia i jego przyczyny poza granice prowadzonej refleksji, a jednocześnie umożliwi wniknięcie w mechanikę procesu podawania wytwarzanemu podmiotowi (S) symboli-znaczących przez Innego (A). W tej kwestii J. Lacan czerpie obficie z klasycznej psychoanalizy i wskazuje na funkcję Ojca, która polega na rozerwaniu pierwotnej symbiotycznej relacji matka-dziecko ${ }^{54}$. Pierwszą po narodzinach fazą ontogenezy osobnika z gatunku Homo sapiens sapiens jest bowiem relacja diadyczna, w której osesek jest całkowicie uzależniony biologicznie od matki: bez jej opieki i regularnego o d-żyw(i)ania zoe dziecka nie byłoby możliwe do utrzymania. Początkowo

50 J. Lacan, Seminarium I. Pisma techniczne Freuda, Warszawa 2017, s. 269.

51 Zob. J. Schodowski, op. cit., s. 82.

52 Zob. ibidem.

53 ,[R]elacja symboliczna definiuje pozycję podmiotu jako widzącego. To mówienie, funkcja symboliczna, jest tym, co określa wyższy lub niższy stopień doskonałości, pełni, przybliżenia wyobrażeniowego. W tym ujęciu czyni się rozróżnienie między Ideal-Ich a Ich-Ideal, między ja idealnym a ideałem ja. Ideał ja zawiaduje grą relacji, tym, od czego zależy całokształt relacji z innym człowiekiem. Od tejże relacji z innym człowiekiem zależy zaś mniej lub bardziej zadowalający charakter struktury wyobrażeniowej" — J. Lacan, Seminarium I..., s. 266-267.

54 Zob. J. Lacan, Imiona-Ojca..., s. 36-37. 
niemowlę, nie dostrzegając swoich granic względem środowiska, trwa w pierwotnej panteistycznej fazie „bycia wszystkim”, nie jest mu dane doświadczenie separacji między sobą a matką (światem). Jednakże w tę diadyczną tożsamość wkracza Trzeci: Ojciec, rozumiany nie biologicznie, ale funkcjonalnie jako instancja rozrywająca dziecięco-matczyną symbiozę, czemu J. Lacan daje wyraz poprzez operowanie pojęciem Imienia-Ojca (le Nom-du Père $)^{55}$.

Ojciec przez w prowadzenie Zakazu dostępu do matki przerywa diadyczną relację, którą charakteryzowała bezpośredniość. Przez swoje „nie” uzależnia dostęp do matki od swojej zgody, a więc znosi fantazmat dziecka, ukazując, że to on jest pragnieniem matki ${ }^{56}$. Używając Zakazu, pierwszego Symbolicznego, Ojciec wprowadza barierę dla narcystycznego, natychmiastowego spełniania pragnień dziecka i rozkoszowania się (jouissance) tym spełnianiem ${ }^{57}$. Wprowadzenie w przestrzeń dziecka Zakazu symbiozy z matką zawiązuje sytuację edypalną i przenosi protopodmiot w rejestr Symbolicznego: Ojciec-Inny (A) staje się prymarnym źródłem znaczących, które posłużą do upodmiotowienia dziecka, a libidalne dążenie do rozkoszowania się (jouissance) wymusi głębsze wejście w język. Dziecko musi bowiem zrozumieć, czego domaga się od niego Ojciec, aby znaleźć alternatywną, dozwoloną, drogę do spełniania tkwiących w nim pragnień. Opanowanie języka — sfery symboli-znaczących — staje się więc koniecznością w ontogenezie, która prowadzi w stronę stania-się-podmiotem. Jak zauważa J. Lacan: „tym, co mnie ustanawia jako podmiot, jest moje pytanie" 58 o to, czego chce Ojciec-Inny.

\section{HOMO IURIDICUS - KONSTATACJA 1: „POJMANIE PODMIOTU” PRZEZ PRAWO}

Podążając konsekwentnie za lacanowskim opisem podmiotogenezy, należy stwierdzić, że Trzeci jest niezbędnym warunkiem obecności podmiotu, gdyż bez

55 Zob. np. ibidem, s. 61-94; por. M. Burzyk, Psychoanaliza a polityka: stawka podmiotu, „Diametros” 2013, nr 35, s. 6. Jak podaje Mały słownik psychoanalizy: „Po raz pierwszy termin ten można odnaleźć w seminarium z 1951/1952 r. poświęconym Freudowskiemu przypadkowi Człowieka Wilka, niemniej jednak pierwsze wyjaśnienie, czym jest metafora ojcowska, która wprowadza Imiona-Ojca do badań naukowych, znajduje się we Wstępnej kwestii dotyczacej wszelkiego możliwego leczenia psychoz z 1957/1958 r." — http://www.psychoanaliza.com.pl/?art=3\&tab=mps\&lang= (dostęp: 1.04.2020).

56 Zob. J. Dor, Introduction à la lecture de Lacan, Paris 2002, s. 286. Jak stwierdza Bruce Fink, zakaz Ojca instruuje dziecko, że: „Twoja matka jest moja, ale możesz mieć każdą inną kobietę. [...] To jest to, do czego Ciebie zobowiązuję [wyr. - M.R.]" — idem, Kliniczne wprowadzenie do psychoanalizy lacanowskiej. Teoria i technika, Warszawa 2002, s. 145.

57 To, czy pragnienie może być w ogóle spełnione (forma dokonana), jest odrębnym problemem na gruncie lacanowskiej psychoanalizy. Prezentacja centralnego dla terapeutycznej psychodynamiki pojęcia jouissance $\mathrm{w}$ teorii J. Lacana wykracza poza ramy prowadzonej refleksji — to trzecie cięcie otwiera przestrzeń dla przyszłych dociekań.

58 J. Lacan, Funkcja i pole mówienia i mowy w psychoanalizie, Warszawa 1996, s. 112-113. 
niego nie ma Symbolicznego ${ }^{59}$, który zgodnie z etymologią (gr. $\sigma 0 \mu \beta \dot{\alpha} \lambda \lambda \omega$ (symbállō) — „zbieram” lub „porównuję”, „łączę”, „,spajam”) spaja ludzką psychikę w pojedynczą całość. Rejestr Symbolicznego jest elementem transcendentnym wobec narcyzmu jednostki, służy oddzieleniu od własnych fantazmatów, a zatem jest rejestrem panowania, który — jak zauważył J. Lacan — realizuje się poprzez prawo i winę ${ }^{60}$. Myśl tę pogłębia P. Legendre, jego zdaniem we współczesnej „ultranowoczenej kulturze"61 Zachodu w pozycji Trzeciego znajduje się twór ze swojej istoty językowy, który realizuje funkcję symboliczną różnicowania podmiotu przez mowę, czyli praw o jako in stytucja oddzielenia ${ }^{62}$. Normatywny przekaz prawa skierowany do osobników z gatunku Homo sapiens sapiens odgrywa rolę Zakazu pochodzącego od funkcjonalnie rozumianego Ojca. Prawo jest zinstytucjonalizowanym Trzecim, za sprawą którego jednostka uzmysławia sobie skalę swojego oddzielenia, granice swojej podmiotowości, poprzez „dyskurs nieodstępności”"63, czyli obwieszczenie jej, co jest poza jej zasięgiem. Jednostka musi stanąć wobec narzuconych jej ograniczeń, które rozbija infantylne wyobrażenie o byciu omnipotentną całością, jednocześnie poprzez łańcuchy znaczących zakodowane w prawie podmiot otrzymuje szansę na symboliczne wyrażenie i zracjonalizowanie tychże ograniczeń.

Tekst prawa okazuje się współczesnym wehikułem substancji Ojca, która jest wpisana w konstrukcje prawne. Tam zakodowany jest Inny, który zapewnia każdej jednostce wejście w mowę i oddzielenie od własnego narcystycznego obrazu, a tym samym umożliwia socjalizację aspołecznych popędów nieświadomego, które S. Freud przedstawił w micie hordy pierwotnej jako kazirodztwo i zabójstwo. Wedle historii przedstawionej w Totem i tabu pierwotna horda była rządzona przez ojca-samca dominującego, który zakazał swoim synom kontaktów seksualnych z zawłaszczonymi przez niego kobietami. Synowie obalili swojego ojca, zabijając go i dokonując aktu kanibalizmu na jego ciele. Opanowani przez wstyd utrwalili jednak w zawiązanej społeczności klanowej zakaz kazirodztwa $\mathrm{w}$ formie egzogamii oraz ustanowili święte wyobrażenie zabitego (pra)ojca — Totem ${ }^{64}$. W ten sposób pierwsze ludzkie społeczeństwo (klan) zostało oparte na Tabu — Zakazie, który obejmuje zakaz kontaktów seksualnych wewnątrz własnej grupy rodowej (zakaz kazirodztwa) oraz zakaz zabijania zwierzęcia totemicznego, które przechodzi w zakaz zabójstwa członków własnej wspólnoty. Wedle P. Legendre’a we współczesnym świecie Zachodu to właśnie prawo znajduje się w miejscu Tabu, wyrażając podmiototwórczy Zakaz ${ }^{65}$.

\footnotetext{
59 Zob. J. Lacan, Seminarium I..., s. 295.

60 J. Lacan, Imiona-Ojca ..., s. 36-37.

61 P. Legendre, Inny wymiar prawa..., s. 5.

62 Ibidem, s. 11.

63 Ibidem.

64 Zob. S. Freud, Totem i tabu, Warszawa 1993, s. 139-140.

65 Zob. P. Legendre, Inny wymiar prawa..., s. 12.
} 
Prawo to Inny, który wprowadza porządek w chaotyczne („metonimiczne”) identyfikacje jednostki z Wyobrażeniowymi: fantazmatami, kolejnymi Ja idealnymi (le moi). Współczesne systemy prawne są nośnikami heteronomicznych norm (zakazów) postępowania, a zatem: (1) wprowadzają jednostkę w separacyjną relację z Innym, który reprezentuje wobec pomiotu in statu nascendi zewnętrzne panowanie; (2) zawierają w sobie „element transcendentny” względem jednostki, a zatem autonomiczny wobec jej wyobrażeń, który stanowi w triadzie rejestrów J. Lacana kryterium demarkacji Symbolicznego i Wyobrażeniowego ${ }^{66}$. W konsekwencji prawo przynależy do rejestru Symbolicznego, co nie zamyka możliwości powstawania jurydycznych fantazmatów (Wyobrażeniowe). Wręcz przeciwnie lacanowska topologia zasygnalizowana przez wprowadzenie schematu numer 1 unaocznia, że proces podmiotogenezy obejmuje interakcję Symbolicznego i Wyobrażeniowego, albowiem poprzez wyobrażeniowe identyfikacje w miejscu $i(a)$ z tym, co pochodzi od Innego (A), jednostka wytwarza swoje Ja idealne $(m)$, które przez dalsze zespolenie w punktacji $[s(\mathrm{~A})]$ ze znaczącymi pochodzącymi od Innego (A) pozwala na internalizację wzorów myślenia i postępowania zakodowanych w Ideale Ja [I(A) ${ }^{67}$. Właśnie owo Ideal-Ich, które konstytuuje człowieczy podmiot, jest prawnym kodem, strumieniem symboli i emblematów wpisanym w prawne instytucje, z czego J. Lacan zdawał sobie sprawę, formułując teorię psychoanalityczną jako integrującą pierwiastki psychologiczne i społeczne ${ }^{68}$. Dlatego też w ramach „fabrykacji” podmiotu przez prawo dochodzi nie tylko do ustanowienia zewnętrznych granic ludzkiego zachowania i podległości, lecz kształtuje się relacja autorytetu, który oddziałuje także na poziomie emocjonalnym, to znaczy prawo poprzez wzbudzanie strachu i miłości, fascynacji i lojalności wiąże kształtowany przez siebie podmiot z własnym teatrem prawdy i sprawiedliwości ${ }^{69}$.

Tak radykalną tezę zdaje się potwierdzać dowód kliniczny analizowany przez P. Legendre'a, to jest przypadek kaprala Denisa Lortiego, który 8 maja 1984 roku dokonał zbrojnego napadu na siedzibę kanadyjskiego Zgromadzenia Narodowego w Ottawie, gdzie zabił trzy osoby i ranił kolejnych osiem ${ }^{70}$. Analizując zachowania, wypowiedzi i biografię sprawcy, P. Legendre zwraca uwagę na postać brutalnego i agresywnego ojca kaprala Lortiego, alkoholika, utrzymującego kazirodczy związek ze swoją córką, najstarszą siostrą zamachowca, z którego to związku

66 Zob. J. Lacan, Imiona-Ojca..., s. 36.

${ }^{67}$ Egzegeza pism J. Lacana prowadzi do jednoznacznego wniosku, że prawo przynależy do rejestru Symbolicznego, ale jednocześnie oddziałuje na pole Wyobrażeniowego. Dopiero uwzględnienie dynamiki podmiotogenezy, zobrazowanej w psychoanalitycznej topologii, pozwala na rozwinięcie intuicji dotyczącej wyobrażeniowej funkcji prawa, lecz równocześnie nie pozwala na zaaprobowanie lokacji prawa w rejestrze Wyobrażeniowego, którą zaproponowano w R. Mańko, $W$ stronę krytycznej..., s. 273-275.

68 Zob. pogląd Jacques'a-Alaina Millera w J. Schodowski, op. cit., s. 82, przyp. 36.

69 Zob. P. Goodrich, „Nieświadome jest prawnikiem”. Psychoanaliza i prawo w dziele Pierre'a Legendre'a, „Kronos” 2010, nr 3, s. 61.

70 Opis stanu faktycznego można znaleźć w ibidem, s. 40-41. 
narodziła się jego młodsza ,siostra”. Lortiego seniora P. Legendre odczytuje jako symbol „ojca poza Prawem”, który zaburzył psychodynamiczny mechanizm identyfikacji Lortiego syna z własnym rodzicem. Niedomknięty proces filiacji doprowadził w wypadku D. Lortiego do dramatycznych skutków, albowiem odrzucając miejsce ojca, sprawca zamachu nie mógł ukonstytuować się jako zdrowy podmiot. Miejsce ojca zostaje zatem połączone z fantazmatem tyrana, który obejmuje swoim ekranowaniem miejsce Ojca-Trzeciego. Chcąc wyrwać się spod panowania strachu, który wywołuje naturalna identyfikacja z ojcem tyranem, D. Lortie przystępuje do działania: chce uciec od prześladującego go fantazmatu przez „opętańczy ceremoniał" polegający na zabiciu rządu Quebecu, który — jak powie po zamachu — „miał twarz jego ojca"71.

Proces karny kaprala Lortiego zostaje odczytany przez P. Legendre'a jako włączenie perspektywy odniesienia, w której prawo - instytucjonalny Trzeci — może umożliwić D. Lortiemu dostrzeżenie rozbicia własnego podmiotu, przekroczenie fantazmatu ojca tyrana w prawie (poprzez rytuały procedury sądowej) i wpisanie w genealogię ludzkiej podmiotowości, co mogłoby skutkować zjednoczeniem oskarżonego z tym, co ludzkie, ale nie przez obłąkańcze działanie, lecz za pośrednictwem wspólnego Trzeciego ${ }^{72}$. Terapeutyczna moc prawa objęłaby wówczas również poziom emocjonalny Lortiego pacjenta. Jest to jednak spekulacja psychoanalityczna, która wymaga przyszłej weryfikacji w analogicznym przypadku, i z tego powodu nie powinna przesłaniać tego, co uwypukla kazus D. Lortiego: uciekając się do eksplozji przemocy (zamachu), kapral dążył do wymazania negatywnego fantazmatu ojca tyrana, który zgodnie z mechaniką filiacji zagrażał Ja idealnemu poprzez generowanie strachu przed staniem się takim jak jego ojciec. Psychika D. Lortiego „pomyliła” jednak z sobą dwie odmienne postaci ojcostwa: Wyobrażoną i Symboliczną, to znaczy, pragnąc wejść w miejsce Ojca (Symboliczne), ale jednocześnie bojąc się przeobrażenia we własnego ojca tyrana (Wyobrażeniowe), zamachowiec skierował swoją agresję wobec zinstytucjonalizowanej zasadzie autorytetu ${ }^{73}$.

W świetle (psycho)analizy przypadku kaprala Lortiego wzmacnia się kluczowa teza P. Legendra, że ludzka podmiotowość do swojego ukonstytuowania się wymaga instytucji prawnych. To prawo jest Innym-Ojcem współczesnej podmiotowości, albowiem w kategoriach zakodowanych w prawie cywilnym, którego genealogia sięga rzymskiego tworzywa cywilizacji, podmiot ludzki zyskuje tożsamość i moc działania, rozpoznając siebie jako przyczynę w sferze społecznej ${ }^{74}$.

71 Zob. P. Legendre, Zbrodnia kaprala Lortiego, „Kronos” 2010, nr 1, s. 143-154; przywołanie wypowiedzi Denisa Lortiego — zob. P. Goodrich, op. cit., s. 41.

72 Zob. P. Legendre, Zbrodnia..., s. 152-154.

73 Podobnie P. Goodrich, op. cit., s. 47.

74 Do takich wniosków dochodzi Tatiana Chauvin po lekturze Leçons IV, VI i Ce que nous appelons le droit P. Legendre'a — por. T. Chauvin, op. cit., s. 13-14 i 20. 
W ultranowoczesności podmiot zostaje więc „porwany przez prawo"75, którego rolą jest - jak dosadnie stwierdza P. Legendre - ustanowienie życia (vitam

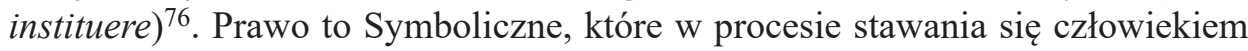
J. Lacan wychwycił jako instancję determinującą obrazy (imago) Ja, poprzez które jednostka pojmuje samą siebie: patrząc na schemat 1, można dostrzec, że na miejsce $i(a)$, gdzie dokonuje się identyfikacja wyobrażeniowa, oddziałuje Inny-Prawo (A), wytwarzając Ja idealne $(m)$ jednostki, które dryfuje w stronę prawnych-znaczących $^{77}$. W miejscu punktacji $[s(\mathrm{~A})]$ dochodzi do zespolenia owych subiektywnych obrazów z wzorcem podmiotowości zakodowanym w prawie, a więc prawo „rodzi podmiot”78, który należy określić mianem Homo Iuridicus, czyli człowieka skonstruowanego przez prawo.

\section{HOMO IURIDICUS - KONSTATACJA 2: DOGMATYKA PRAWNICZA JAKO „MONTER” PODMIOTU}

Jeżeli prawo jest instrumentem ustanawiającym życie, a jego podstawową właściwością tekstualną jest niedookreśloność właściwa symbolom, to konieczność instancji hermeneutycznej — urzędu wykładni prawa — staje się oczywista. Peter Goodrich zwraca uwagę na ukrytą poetykę tekstów prawnych, które poprzez metafory kodują symbole ustanawiające „duszę” podmiotu. Do odczytania tych znaczących niezbędne jest uznanie tego, co średniowieczni ju-

75 P. Goodrich, op. cit., s. 43.

76 Zob. P. Legendre, Inny wymiar..., s. 5; idem, Antropologia dogmatyczna..., s. 19-20. Formuła vitam instituere bierze swój początek z fragmentu Marcjana (jurysta z III wieku n.e.), umieszczonego w księdze I Institutiones, w której cytowany jest w języku greckim ustęp z Demostenesa. Fragment Marcjana — jak ustalił Pierre Legendre (romanista) — został w VI wieku n.e. włączony przez cesarza Justyniana do księgi Digestów, a następnie przez przekład Burgundiusza z Pizy z końca XII wieku i przekaz Godefroida, szesnastowiecznego prawnika i humanisty, dotarł do niemieckiego wydania Digestów Mommsena w XIX wieku. W thumaczeniu łacińskim Godefroida formuła brzmi: „,communis sponsio civitatis, ad cuius praescriptum omnes, qui in ea republica sunt, vitam instituere debent”. P. Legendre odczytuje ową formułę vitam instituere jako emblemat, który zwięźle utrwala symboliczną resp. podmiototwórczą funkcję prawa, albowiem określa źródła prawa jako „to, co zostało ustanowione wspólnie w państwie, wedle czego wszyscy muszą żyć [wyr. M.R.]" - ibidem, s. 35-36.

77 W konsekwencji należy skorygować mylące uproszczenie Petera Goodricha, jakoby to prawo miało być obrazem umożliwiającym podmiotom wymiar społeczny (zob. idem, op. cit., s. 46-47). Gdyby prawo było obrazem, należałoby do rejestru Wyobrażeniowego, a więc byłoby tylko (patologicznym) fantazmatem. Tymczasem w świetle teorii psychoanalitycznej J. Lacana prawo jest Symbolicznym, a więc instancją, która pozwala okiełznać Wyobrażeniowe. Oczywiście takie rozpoznanie miejsca prawa nie wyklucza możliwości powstawania różnych wyobrażeń prawa, a więc jurydycznych fantazmatów. Otwiera to ciekawą przestrzeń dociekań nad potrzebą jurydycznej psychoterapii.

78 J. Lacan, Inny wymiar..., s. 12. 
ryści nazywali officium poetae, czyli funkcji poetyckiej tekstu prawnego. Litera prawa sama w sobie nigdy nie była bowiem samowystarczalna, co przedstawiał już Justynian w Noweli 146: non solis litteris adhaerare (,trzymać się nie tylko litery" $)^{79}$. Komentowanie i interpretowanie tekstu prawnego jest niezbędne do przebicia się przez skorupę liter. Świetnie zdawali sobie z tego sprawę średniowieczni juryści, którzy podkreślali konieczność sięgania po narzędzia retoryczne, argumentacyjne i dokonywanie ocen w pracy z tekstem prawnym. Jednakże już od św. Pawła z Tarsu bierze swój początek metadyrektywa interpretacyjna, że to nie litera, lecz duch określa znaczenie prawa, albowiem tekst składa się li tylko z martwych liter (litera mortua $)^{80}$. W antycznej tradycji prawniczej analogiczną myśl wyrażają Digesta (1.3.17), powołując się na Celsusa: Scire leges non hoc est verba earum tenere, sed vim ac potestatem (,Znajomość ustaw nie polega na znajomości ich dosłownego brzemienia, lecz na »zrozumieniu« ich znaczenia i celu"81).

Przepis prawny jest jedynie sekwencją „,martwych liter”, która dla swojego ożywienia w czynnik podmiototwórczy wymaga wprowadzenia anima legis przez prawnika lub sędziego ${ }^{82}$. Juryści wedle antycznej formuły Ulpiana są „kapłanami” (sacerdotes) prawa, ponieważ kultywują sprawiedliwość 83 . Wchodząc w zadanie hermeneutyczne, pojmując prawo jako wyzwanie interpretacyjne, prawnicy ożywiają instytucje-emblematy niezbędne do odnawiania się ludzkiej podmiotowości, zapewniają dostęp do rejestru Symbolicznego. Na tym właśnie polega sprawowanie przez dogmatyków prawa i sędziów urzędu (officium) wykładni prawa, względem którego jednostka Homo sapiens sapiens czuje się przymuszona do uspójnienia swojego zachowania. Jak wskazuje bowiem analiza genealogiczna przeprowadzona przez Giorgia Agambena, sprawowanie officium pozwala jednostce odnaleźć właściwe zachowanie, czyli takie, które jest oczekiwane wśród osób związanych pewną skodyfikowaną (a więc utrwalaną symbolicznie) relacją społeczną ${ }^{84}$. Tym

79 Zob. P. Goodrich, op. cit., s. 57-58.

80 „On też sprawił, żeśmy mogli stać się sługami Nowego Przymierza, przymierza nie litery, lecz Ducha; litera bowiem zabija, Duch zaś ożywia” (2 Kor 3, 6).

81 Tłumaczenie za: Digesta Iustiniani. Digesta Justyniańskie. Tekst i przekład, t. 1 (ks. 1-4), red. T. Palmirski, Kraków 2013, s. 181. Zob. także P. Goodrich, op. cit., s. 58, gdzie proponuje się inne tłumaczenie sentencji Celsusa: „znać prawo nie znaczny znać jego słowa, lecz jego siłę i władzę"; tam też przywołano fragmenty z F. Bacona i sir E. Coke'a, ukazujące transmisję omawianej antycznej i biblijnej metadyrektywy pracy z tekstem (prawnym).

82 Zob. P. Goodrich, op. cit., s. 58.

83 Zob. Digesta Iustiniani $(1,1,1)$, s. 159; por. P. Legendre, Inny wymiar..., s. 11. Wypełnianie przez prawników funkcji „kapłanów”, którzy w państwie sekularyzowanym dysponują „środkami produkcji duchowej”, może być wydobyte także z koncepcji socjologicznej Leszka Nowak (zob. idem, Wolność i władza: Przyczynek do nie-Marksistowskiego materializmu historycznego, Poznan 1981, s. 195-199), na co zwraca uwagę A. Sulikowski, The return of forgotten critique: Some remarks on the intellectual sources of the Polish populist revolution, „Review of Central and East European Law" 2020, nr 45, s. 391.

84 Zob. G. Agamben, Opus Dei. An Archaeology of Duty, Stanford, CA 2013, s. 72. 
sposobem stosowanie prawa - Symbolicznego — prowadzi do konstytuowania i rewitalizacji podmiotowości jednostki ludzkiej.

W sekularyzowanej ultranowoczesności to właśnie prawo i prawnicy wchodzą w miejsce religijnych prawd i rytuałów, które służą do odtwarzania podmiototwórczego Zakazu. Rehabilitując pojęcie dogmatyki, P. Legendre zwraca uwagę, że pod pojęciem doxa ukrywają się dwie płaszczyzny znaczeniowe: jedna wskazuje na ,założycielskie aksjomaty”, zasady lub decyzje, a druga — na zaszczyty, upiększanie, dekoracje. Natomiast wyrażenie dogma oznacza to, co się zdaje, co się pojawia, daje się ujarzmić, jest ujawnione. Dogmatyka jest zatem dziedziną „prawdy legalnej”, to znaczy tego, co zostało ujawnione w zaszczytny sposób, gdyż powinno zostać wypowiedziane. $Z$ tego względu dogmatyka jest wyspecjalizowana w reprodukowaniu emblematów (z gr. $\check{\varepsilon} \mu \beta \lambda \eta \mu \alpha$ - „wypukła dekoracja”, coś, co jest wyryte w żelazie lub drewnie), które tworzą teatr symboli, w którym osobnik z gatunku Homo sapiens sapiens ma odnaleźć swoją podmiotową rolę ${ }^{85}$.

Ustanowienie instytucji odniesienia $\mathrm{w}$ prawie wymaga realizowania funkcji dogmatycznej, albowiem Zakaz nie ma podstaw naukowych (wszakże stoi w miejscu Tabu), a zatem nie może być uzasadniony inaczej niż tylko przez teatralizację i posłużenie się metaforą. Temu właśnie służy dogmatyka prawnicza, która podejmuje się $\mathrm{w}(\mathrm{y}) \mathrm{zy} w a j a ̨ c e g o \mathrm{w}$ językowej naturze prawa zadania interpretacyjnego, wnika w Tekst prawny, aby wielokrotnie inaczej wypowiedzieć jedne i te same symbole. Podtrzymanie funkcjonalnego połączenia zachodzącego pomiędzy tekstami prawnymi, ich wykładnią a dogmatyką prawniczą jest niezbędnym warunkiem trwałości Symbolicznego, bez którego w sekularyzowanym świecie Zachodu zatracone zostaną ścieżki wytwarzania podmiotów ludzkich ${ }^{86}$.

Dogmatyka prawnicza pozwala na urzeczywistnienie pewnej autopojetyczności prawa, gdyż konieczne w systemie korekty powinny dokonywać się nie poprzez stawianie prawa przed „trybunałem uniwersalnego sumienia w postaci opinii publicznej czy obywatelskiej"87, ale poprzez wnioski de lege ferenda i de lege lata, które przynależą do dogmatycznego autorytetu, a więc nie dekonstruują autorytetu samego prawa (Innego-Ojca). Podążając za Pierre'em Legendre'em, można wskazać zadanie dogmatyki prawa (nauk prawnych) — jest nim scalenie z sobą trzech ludzkich sfer:

1. biologicznej egzystencji jednostki, w której ulokowane jest ludzkie ciało z jego potrzebami - dogmatyki prawnicze poprzez odczytywanie Tekstu prawnego identyfikują warunki formalne i społeczne zaspakajania tych potrzeb (na przykład nauka prawa cywilnego i nauka prawa karnego);

85 Zob. P. Legendre, Antropologia dogmatyczna..., s. 20-21.

${ }^{86} \mathrm{~W}$ ten sposób psychoanalityczne rozumienie dogmatyki prawniczej P. Legendre'a odczytuje Anton Schütz i przypisuje temu stanowisku cechy konserwatyzmu — zob. idem, Synowie pisma, synowie gniewu: Pierre’a Legendre'a krytyka racjonalnego prawodawstwa, „Kronos” 2010, $\mathrm{nr} 3$, s. 77.

87 Ibidem, s. 76. 
2. ludzkich pragnień, które nie są tożsame $\mathrm{z}$ biologicznymi potrzebami, ale dotyczą wzajemnej identyfikacji za sprawą wydobytego przez dogmatyki prawnicze z Tekstu prawnego fundującego odniesienia (Boga, przywódcy, idei, instytucji), które wytwarza wspólnotę - dodajmy — polityczną (na przykład nauka prawa konstytucyjnego);

3. społeczeństwa, w którym jednostka zostaje włączona w pewną kulturę, której transmiterem jest między innymi porządek prawny współtworzony przez dogmatyki prawnicze (na przykład nauka prawa konstytucyjnego i administracyjnego $)^{88}$.

Dogmatyki prawnicze, przejmując w nowoczesności funkcję dogmatyk religijnych, w pewnym stopniu powróciły do swoich sakralnych korzeni rzymskich i podjęły się zadania wy powiadania Zakazu zapisanego w Tekście prawnym. Zapewniają one autonomię instytucji odniesienia, albowiem poprzez formułowane i modyfikowane poglądy prawne - dogmaty prawne - aktualizują dziejowo treści symboliczne bez uciekania się do innych dyskursów, w szczególności scjentystycznego ${ }^{89}$.

W konsekwencji dogmatyka prawna okazuje się uczestniczyć w wytwarzaniu Homo Iuridicus: jeżeli prawo jest „taśmą produkcyjną” ludzkich podmiotów, to dogmatyka prawnicza jest tam „monterem”. Poprzez ożywianie emblematów prawnych w drodze doktrynalnej wykładni prawa uruchamia ona instytucję odniesienia, Innego-Trzeciego, którego substancja jest uśpiona w prawie. To funkcjonalne sprzężenie systemu prawnego i dogmatyki prawa pozwala zatem na domknięcie psychoanalitycznego procesu podmiotogenezy. Wytwarzanie podmiotu politycznego, a więc samej polityki, resp. polityczności, nie byłoby możliwe bez obecności dwóch jurydycznych czynników: tekstu prawnego i dogmatyki prawa.

\section{KONKLUZJA (NIE)ZAMYKAJĄCA O JURYDYCZNOŚCI POPRZEDZAJĄCEJ POLITYCZNOŚĆ}

Wracając do pytania otwierającego prowadzone dociekania, należy skonkludować, że sekwencja przeprowadzonych refleksji odsłoniła pod warstwami przeanalizowanej ikony Zoon Politikon figurę Homo Iuridicus. Wejście jednostki w Prawo, to jest obszar logiki Zakazu, jest tożsame z włączeniem w rejestr Sym-

88 Por. rekonstrukcja myśli P. Legendre'a w G. Locke, F. Maiolo, La guerre totale industrielle. Kilka uwag o zarzadzaniu jako globalnym fundamentalizmie, „Kronos” 2010, nr 3, s. 89-90; wskazanie zadań dogmatycznych w poszczególnych sferach i przykłady konkretnych nauk prawnych - M.R.

89 Tak odczytana natura dogmatyki prawa thumaczy upodobanie do metody formalno-dogmatycznej w obszarze szczegółowych nauk prawnych i awersje do metod empirycznych — zob. dane zebrane i przeanalizowane w D. van Kędzierski, Metodologia i paradygmat polskich szczegótowych nauk prawnych, „Transformacje Prawa Prywatnego” 2018, nr 3, s. 5-59. 
bolicznego, w którym osobnik z gatunku Homo sapiens sapiens jako „Zwierzę mówiące” właśnie w języku normatywności znajdzie „łańcuch znaczących” dla poszukiwanej podmiotowości. Bez tego psychodynamicznego procesu jednostka jest pozbawiona ludzkiego życia (bios) — to bowiem rolą Prawa jest ustanawianie życia (vitam instituere) — a zatem nie może wkroczyć w pole polityki i we właściwe polityczności procesy rozpoznawania „przyjaciól” i „,wrogów”. Nie będąc sobą, nie można konkluzywnie ustosunkować się do innych ludzi, a więc aby być Zoon Politikon, trzeba być ukonstytuowanym jako Homo Iuridicus.

Podmiototwórcze Prawo to każda struktura normatywna, która realizuje logikę Zakazu, czyli transcendentnie wobec jednostki — z pozycji Innego — unaocznia tejże granice jej własnej sprawczości, wydobywając ją w procesie ontogenezy z panteistycznego fantazmatu omnipotencji. Funkcja Zakazu może być realizowana przez różne formy normatywności charakterystyczne dla rozmaitych odcinków kulturowego spectrum: od norm obyczajowych przez moralne po normy prawa pozytywnego. To obecność normatywności - Prawa par excellence (dlatego też pisanego od wielkiej litery dla odróżnienia od prawa w znaczeniu prawa pozytywnego, wytwarzanego w ramach inżynierii legislacyjnej wyspecjalizowanych instytucji ludzkich) - konstytuuje potencjał podmiototwórczy usystematyzowanych poglądów etycznych na życie społeczne, to jest ideologii. Zaproponowany przez Louisa Althussera mechanizm podmiotogenezy oparty na ,interpelacji ideologicznej" ${ }^{90}$ wydaje się trafny jedynie pod warunkiem dostrzeżenia normatywnej warstwy ideologii. „Interpelacja” (interpellation) jednostki polega na gwałtownym zwróceniu się z żądaniem ujawnienia przez nią własnej tożsamości, co L. Althusser wyjaśnia, używając metafory policyjnej: biologiczna jednostka ludzka za sprawą interpelacji przeobraża się w podmiot, albowiem jak na najbanalniejsze wezwania policjanta „Hej, ty tam!” musi rozpoznać samą siebie jako adresata wezwania, a następnie zwrócić się w stronę źródła żądania, tym samym wystawiając się na jego oddziaływanie ${ }^{91}$. W tym miejscu opisu podmiotogenezy w ujęciu L. Althussera pojawia się luka: aby interpelacja uruchomiła kształtowanie jednostki biologicznej w podmiot wedle wzoru antropologicznego zakodowanego w ideologii, interpelowany musi doświadczyć oddziaływania Zakazu. Bez podania normatywnego wzorca całokształtu zachowań — bycia-w-świecie ludzi który jednostka biologiczna ma realizować między innymi w sferze polityczności, resp. polityki, stając się tym samym podmiotem, osobnik z gatunku Homo sapiens sapiens nie będzie mógł „rezonować” w odpowiedzi na interpelujące wezwanie Innego. Bez komponentu normatywnego ideologia byłaby li tylko mniej lub bardziej trafnym opisem świata społecznego, podczas gdy de facto jest jednym z jego kreatorów poprzez interpelowanie jednostek w podmioty ludzie. Zasadą, przy-

90 Zob. L. Althusser, Ideologie i aparaty ideologiczne państwa, Warszawa 2006, s. 23.

91 Zob. ibidem; koncepcję interpelacji ideologicznej jako potencjalnego narzędzia krytycznej analizy prawa przedstawiono w R. Mańko, Koncepcja interpelacji ideologicznej a krytyczny dyskurs o prawie, „Archiwum Filozofii Prawa i Filozofii Społecznej” 2014, nr 1, s. 41-54. 
czyną i mocą (arché) tego procesu jest jednak Prawo, nieoficjalnie i nieformalnie wpisane w plazmatyczną substancję ideologii.

$\mathrm{Z}$ racji wskazanych cech normatywność obecna w ideologii jawi się jako „ułomna” jurydyczność, która pozbawiana jest charakterystycznego dla prawa pozytywnego nieustannego procesu dążenia do formalnego domknięcia. Nieistnienie zinstytucjonalizowanego urzędu (officium) wykładni i stosowania treści normatywnych oraz realizacji funkcji dogmatycznej na wysoce ustrukturyzowanym poziomie sprawiają, że Prawo wpisane w ideologię przedkłada jednostce biologicznej mniej konkluzywne, a tym samym bardziej chybotliwe składowe Ideału Ja (Ich-Ideal), do którego dążąc, jednostka przeobraża się w ludzki podmiot. W konsekwencji jednostka jest $w$ wyższym stopniu narażona na błędne identyfikacje wyobrażeniowe zaburzające proces podmiotogenzy. $Z$ tego też względu sfera ideologii jest w wyższym stopniu źródłem neurotycznych następstw nieokiełznania Wyobrażeniowego przez Symboliczne. Inaczej dynamika tego procesu wygląda w obszarze Prawa sformalizowanego w prawo pozytywne: jurydyczność realizowana poprzez „ożywianie” tekstu prawnego w ramach urzędu sędziowskiego i dogmatyki prawniczej pozwala na zdecydowanie wyraźniejsze przywoływanie Innego-Trzeciego, który jest źródłem bardziej konkluzywnego Zakazu.

Asymetria procesów symbolizacji do Ideału Ja (Ich-Ideal) w praktykach ideologicznych i prawnych, z przewagą tej ostatniej, nakazuje wrócić do myśli P. Legendre'a, że podmiotowość prawna jest w ultranowoczesnej cywilizacji Zachodu jedyną dostępną „Zwierzęciu mówiącemu” formą podmiotowości ${ }^{92}$, która trwa za sprawą realizowania funkcji dogmatycznej przez nauki prawne. Pogląd ten domaga się weryfikacji w drodze pogłębionej analizy psychodynamicznych mechanizmów podmiotogenezy oraz oszacowania ryzyka jej neurotycznego zaburzenia w procesach interpelacji ideologicznej i zestawienia wyników z praktyką stosowania prawa uwzględniającego pracę dogmatyczną ${ }^{93}$. Niezależnie jednak od przyszłych ustaleń już teraz można stwierdzić, że przeprowadzona refleksja wskazuje na jurydyczność — Prawo - jako warunek sine qua non ludzkiej podmiotowości. Skoro ukształto-

$92 \mathrm{~W}$ punkcie szczytowym epoki nowoczesności intuicyjnie wyczuł to Franz Kafka, który w Procesie odrysowuje postać pielęgniarki Leni, zajmującej się chorującym adwokatem i mającej z tego tytułu okazję do obserwowania anomalii praktyki prawniczej. Niezwykle intrygujące jest to, że właśnie tę postać, u której doświadczenie życiowe podważa autorytet prawa, ukazując nie-praworządne, lecz raczej dowolne traktowanie podsądnych przez wymiar sprawiedliwości, tym samym zaburzając jej „wejście do prawa”, F. Kafka przedstawia jako mającą defekt niepełnego cielesnego ukształtowania: „Rozgięła u prawej ręki palce środkowy i serdeczny, łącząca je skóra sięgała aż prawie do górnego zgięcia krótkiego palca" — idem, Proces, [w:] idem, Wybór prozy, Wrocław 2018, s. 232. Ten brak prawidłowego różnicowania się palców można odczytać jako symbol niepełnej podmiotowej konstytucji — coś, co powinno podlegać zasadzie oddzielenia, nie zostało poddane prawidłowej separacji.

93 Pewną wskazówką do sformułowania hipotezy wejściowej jest metafora policyjna Louisa Althussera, w której dla wyjaśnienia mechanizmu upodmiotawiania ideologicznego sięga się jednak po instytucję prawną. 
wanie podmiotu prawnego (Homo Iuridicus), choćby ułomne w ramach interpelacji ideologicznej, jest warunkiem polityki, resp. polityczności, to teza o prymarności polityczność nie może być utrzymana. Relacja zachodząca między jurydycznością a politycznością domaga się innego rozpoznania.

\title{
HOMO IURIDICUS VERSUS ZOON POLITIKON - LEGAL DOGMATICS AND THE PRODUCTION OF THE (POLITICAL) SUBJECT
}

\begin{abstract}
Summary
The reflection on the political nature of law and jurisprudence seems to be dominated by the view that the political precedes (chronologically or structurally) the law. Hence the antagonisms of the political sphere, shape the law and its phenomena (legal practice and jurisprudence). However, the thesis about the primacy of the political can be verified by means of an analysis initiated by the perverse question about juridical conditions, without which the political par excellence is not possible. The reflection on the icon of Zoon Politikon reveals the condition of the political in the form of subjectivity of participants of the political sphere, while reaching for the psychoanalytical theory of J. Lacan allows the capture of the psychodynamics of the subjectivity genesis in the case of the "talking animal" (Zoon Logon Echon). The introduction of the Prohibition (Symbolic as coded in law) turns out to be a sine qua non condition of human subjectivity. According to Pierre Legendre, in contemporary society legal dogmatics reproduce the subjectivity-making prohibition, and thus "produces" man: Homo Iuridius, and "establishes his life". At the end, law and legal dogmatics must be recognized as the condition for the emergence of the (political) subject, and thus the political itself.
\end{abstract}

Keywords: the political, politics, Zoon Politikon (political animal), Zoon Logon Echon (talking animal), Homo Iuridicus (legal person), subjectivity, the juridical, prohibition, anthropology, psychoanalysis, jurisprudence, legal dogmatics, Jacques Lacan, Pierre Legendre

\section{BIBLIOGRAFIA}

Agamben G., Homo sacer. Suwerenna władza i nagie życie, Warszawa 2008.

Agamben G., Opus Dei. An Archaeology of Duty, Stanford, CA 2013.

Althusser L., Ideologie i aparaty ideologiczne państwa, Warszawa 2006.

Applebaum A., Gułag, Warszawa 2018.

Arendt H., Kondycja ludzka, Warszawa 2010.

Arystoteles, Polityka, Warszawa 2012.

Bator A., Kaczmarek P., Polityczność nauki prawa i praktyki prawniczej - wprowadzenie, „Przegląd Prawa i Administracji” 110, 2017, s. 9-11.

Biblia Tysiaclecia, Poznań 2003, https://biblia.deon.pl/ (dostęp: 2.04.2020).

Burzyk M., Psychoanaliza a polityka: stawka podmiotu, „Diametros” 2013, nr 35, s. 1-20.

Chauvin T., Prawo jako dyskurs o życiu — antropologia dogmatyczna Pierre'a Legendre'a, „Archiwum Filozofii Prawa i Filozofii Społecznej” 2014, nr 1, s. 5-24.

Digesta Iustiniani. Digesta Justyniańskie. Tekst i przekład, t. 1 (ks. 1-4), red. T. Palmirski, Kraków 2013. 
Dor J., Introduction à la lecture de Lacan, Paris 2002.

Fink B., Kliniczne wprowadzenie do psychoanalizy lacanowskiej. Teoria i technika, Warszawa 2002.

Fink B., Lacan to the Letter. Reading Écrits Closely, Minneapolis 2004.

Freud S., Totem i tabu, Warszawa 1993.

Gajek M., Człowiek jako obywatel w myśli Arystotelesa, „Zoon Politikon” 2010, nr 1, s. 39-48.

Gizbert-Studnicki T., Filozofia polityczna a pozytywistyczna teoria prawa, „Przegląd Prawa i Administracji” 110, 2017, s. 15-39.

Goodrich P., ,,Nieświadome jest prawnikiem”. Psychoanaliza i prawo w dziele Pierre'a Legendre'a, „Kronos” 2010, nr 3, s. 40-64.

Hart H.L.A., Eseje z filozofii prawa, Warszawa 2001.

Havel V., Zmieniać świat. Eseje polityczne, Warszawa 2012.

Henzel-Korzeniowska A., Teoria Jacques'a Lacana i jej pożytek dla doświadczenia psychoanalitycznego, „Edukacja Etyczna” 2013, nr 6, s. 5-15.

Izdebski H., Pierre Legendre — kanonista, romanista, historyk administracji i...?, „Kronos” 2010, nr 3, s. 37-39.

Kafka F., Wybór prozy, Wrocław 2018.

Kędzierski D. van, Metodologia i paradygmat polskich szczegółowych nauk prawnych, „Transformacje Prawa Prywatnego" 2018, nr 3, s. 5-59.

Kijewska A., Wstęp, [w:] Eriugena, Komentarz do Ewangelii Jana (z homilia do Prologu Ewangelii Jana), Kęty 2000, s. 3-38.

Lacan J., Écrits, Paris 1966.

Lacan J., Funkcja i pole mówienia i mowy w psychoanalizie, Warszawa 1996.

Lacan J., Imiona-Ojca, Warszawa 2013.

Lacan, Le moi dans la théorie de Freud et dans la technique de la psychanalyse, Le Seminaire livre II, Paris 1978.

Lacan J., Radiophonie, [w:] idem, Autres écrits, Paris 2001, s. 403-447.

Lacan J., Seminarium I. Pisma techniczne Freuda, Warszawa 2017.

Lacan J., Stadium zwierciadła jako czynnik ksztattujący funkcję Ja w świetle doświadczenia psychoanalitycznego. Referat na XVI Międzynarodowym Kongresie Psychoanalitycznym, Zurich, 17 lipca 1949, „Psychoterapia” 1987, nr 4, s. 5-9.

Lacan J., Télévision, [w:] idem, Autres écrits, Paris 2001, s. 509-546.

Lang H., Język i nieświadomość. Podstawy teorii psychoanalitycznej Jacques'a Lacana, Gdańsk 2005.

Legendre P., Antropologia dogmatyczna. Definicja pojęcia, „Kronos” 2010, nr 3, s. 19-36.

Legendre P., Inny wymiar prawa, „Kronos” 2010, nr 3, s. 5-18.

Legendre P., Zbrodnia kaprala Lortiego, „Kronos” 2010, nr 1, s. 143-154.

Locke G., Maiolo F., La guerre totale industrielle. Kilka uwag o zarządzaniu jako globalnym fundamentalizmie, „Kronos” 2010, nr 3, s. 88-102.

Maty stownik psychoanalizy, http://www.psychoanaliza.com.pl/?art=3\&tab=mps\&l ang= (dostęp: 1.04.2020).

Mańko R., Koncepcja interpelacji ideologicznej a krytyczny dyskurs o prawie, „Archiwum Filozofii Prawa i Filozofii Społecznej" 2014, nr 1, s. 41-54.

Mańko R., Nauki prawne wobec problemu polityczności: zagadnienia wybrane z perspektywy jurysprudencji krytycznej, „Archiwum Filozofii Prawa i Filozofii Społecznej” 2018, nr 3, s. 38-50.

Mańko R., W stronę krytycznej filozofii orzekania. Polityczność, etyka, legitymizacja, Łódź 2018.

Meyer-Kalkus R., Jacques Lacan: Psychoanaliza jako lingwistyka mówienia, „Teksty Drugie” 1998, nr 1-2, s. 5-18.

Michalik G., Podmiot znikajacy - kwestia podmiotowości w psychoanalizie Jacques'a Lacana, „Analiza i Egzystencja” 2018, nr 41, s. 79-99. 
Miller J.A., Mathems: Topology in the teaching of Lacan, [w:] Lacan: Topologically Speaking, red. E. Ragland, D. Milovanovic, New York 2004, s. 28-48.

Mouffe Ch., Polityczność. Przewodnik Krytyki Politycznej, Warszawa 2008.

Nowak L., Wolność i władza. Przyczynek do nie-Marksowskiego materializmu historycznego, Poznań 1981.

Paździora M., Stambulski M., Co może dać nauce prawa polityczność? Przyczynek do dalszych badań, „Archiwum Filozofii Prawa i Filozofii Społecznej” 2014, nr 1, s. 55-66.

Prószyńska M., Schmittiańskie pojęcie polityczności. Neutralizacja w ogniu krytyki, https://teologiapolityczna.pl/magdalena-proszynska-schmittianskie-pojecie-politycznosci-neutralizacja-w-ogniu-krytyki (dostęp: 15.03.2020).

Rakoczy F., Autonomia prawa a problem jego polityczności, [w:] Polityka/polityczność. Granice dyskursu, red. B. Krzysztan, W. Ufel, M. Zieliński, Wrocław 2016, s. 211-228.

Rymkiewicz W., Edytorial, „Kronos” 2020, nr 3, s. 3.

Saussure F. de, Kurs językoznawstwa ogólnego, Warszawa 1991.

Schmitt C., Pojęcie polityczności, [w:] idem, Teologia polityczna i inne pisma, Warszawa 2012, s. 245-314.

Schodowski J., Podmiot pragnienia. Czytając Subversion du sujet et dialectique du désir, „Kronos” 2010, nr 1, s. 75-86.

Schütz A., Synowie pisma, synowie gniewu: Pierre'a Legendre'a krytyka racjonalnego prawodawstwa, ,Kronos” 2010, nr 3, s. 65-87.

Stambulski M., Polityczność w polskiej analitycznej teorii prawa. Zarys problematyki, „Archiwum Filozofii Prawa i Filozofii Społecznej” 2018, nr 3, s. 64-73.

Sulikowski A., Apolityczność w prawoznawstwie. Kryzys idei a zjawisko populizmu, „Archiwum Filozofii Prawa i Filozofii Społecznej” 2018, nr 3, s. 74-85.

Sulikowski A., The return of forgotten critique: Some remarks on the intellectual sources of the Polish populist revolution, „Review of Central and East European Law”2020, nr 45, s. 376-401.

Sulikowski A., Mańko R., Łakomy J., Polityczność prawa i ogólnej refleksji nad prawem: wprowadzenie, „Archiwum Filozofii Prawa i Filozofii Społecznej” 2018, nr 3, s. 5-9.

Zajadło J., Prawoznawstwo - polityczność nauki czy nauka polityczności?, „Przegląd Prawa i Administracji” 110, 2017, s. 41-49.

Zirk-Sadowski M., Metodologie teorii prawa a problem polityczności prawoznawstwa. Aspekt behawioralny i intensjonalny, „Przegląd Prawa i Administracji” 110, 2017, s. 51-62. 